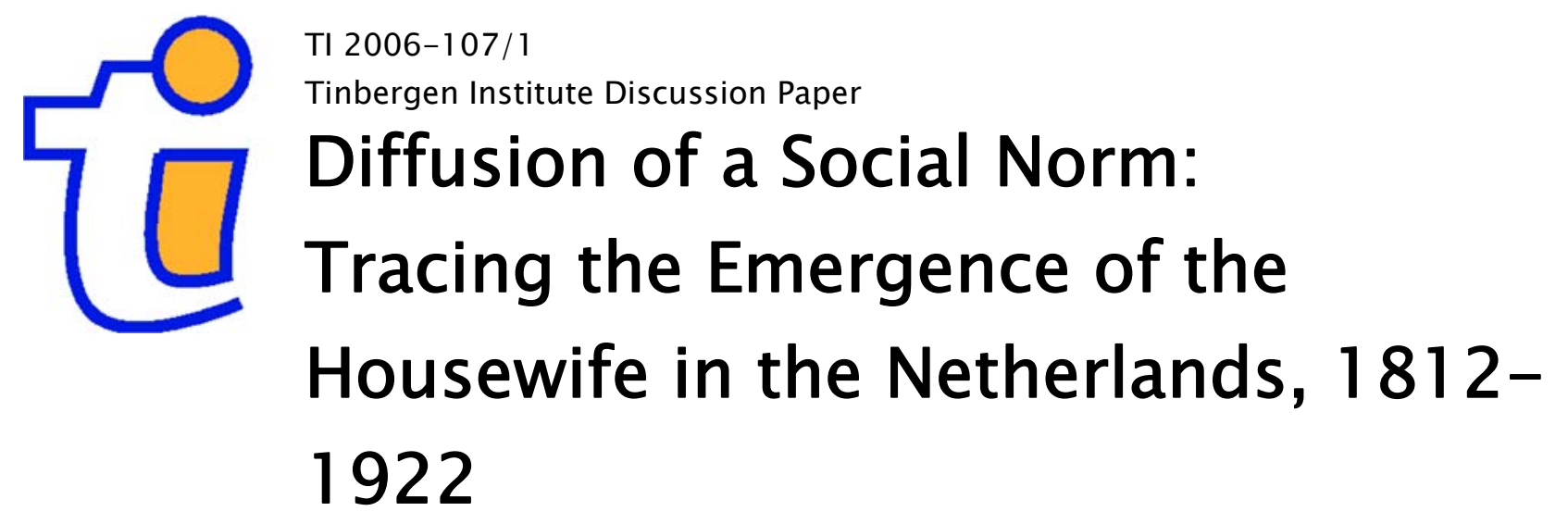

Frans W.A. van Poppe/

Hendrik P. van Dalen ${ }^{2}$

Evelien Walhout ${ }^{3}$

\footnotetext{
${ }^{7}$ Netherlands Interdisciplinary Demographic Institute, The Hague;

2 Erasmus Universiteit Rotterdam, and Tinbergen Institute;

3 International Institute for Social History, Amsterdam.
} 


\section{Tinbergen Institute}

The Tinbergen Institute is the institute for economic research of the Erasmus Universiteit Rotterdam, Universiteit van Amsterdam, and Vrije Universiteit Amsterdam.

Tinbergen Institute Amsterdam

Roetersstraat 31

1018 WB Amsterdam

The Netherlands

Tel.: $\quad+31(0) 205513500$

Fax: $\quad+31(0) 205513555$

Tinbergen Institute Rotterdam

Burg. Oudlaan 50

3062 PA Rotterdam

The Netherlands

Tel.: $\quad+31(0) 104088900$

Fax: $\quad+31(0) 104089031$

Most TI discussion papers can be downloaded at http:/ /www.tinbergen.nl. 


\title{
Diffusion of a Social Norm: Tracing the Emergence of the Housewife in the The Netherlands, 1812-1922 ${ }^{1}$
}

\author{
Frans W.A. van Poppel ${ }^{\mathrm{a}}$, Hendrik P. van Dalen ${ }^{\mathrm{a}, \mathrm{b}}$ and Evelien Walhout ${ }^{\mathrm{c}}$
}

December 1, 2006

(a) Netherlands Interdisciplinary Demographic Institute (NIDI)

P.O. Box 11650

NL-2502 AR The Hague

The Netherlands

(b) Erasmus University Rotterdam

Department of Economics, and Tinbergen Institute

P.O. Box 1738

NL-3000 DR Rotterdam

The Netherlands

Email: vandalen@,few.eur.nl

(c) International Institute for Social History (IISG)

Cruquiusweg 31

NL-1019 AT Amsterdam

The Netherlands

JEL codes: D13, J12, J16, N34

Keywords: marriage, norms, division of labour, housewife, breadwinner

\section{Summary}

The emergence of the housewife in the Netherlands over the period 1812-1922 was strongly influenced by the social norm that women should withdraw from the labour market on the eve of marriage. Adherence to this norm is most clearly reflected in the emergence of the housewife among the lower classes, especially at the close of the nineteenth century among wives of farmers. Women in urban municipalities, however, set the norm far earlier and differences across social classes were significantly larger in towns than in rural areas. Paradoxically, the rise of the housewife did not change work pressures for lower-class women. This paradox is resolved by noting that they substituted registered work for unregistered work, e.g., in house industries, working in the family firm or farm.

(1) In constructing the database we wish to thank Andrew Miles (University of Birmingham) and Bart van de Putte (University of Louvain) for invaluable help with the coding of the occupational titles. Marco van Leeuwen (International Institute for Social History, Amsterdam) placed HISCO's basic coding list at our disposal. We wish to thank the Zeeuws Archives, the State Archives of Limburg (Rijksarchief Limburg), the Historic Centre Overijssel, the Groninger Archives and the Gelders Archives for placing their data at our disposal. Kees Mandemakers (IISG) was very helpful in offering data assistance. 
'Woman!...Thou art created to breastfeed thy children. What a responsibility does thou have with the Creator, when thou, save the most pressing circumstances, let a stranger breastfeed them [..] [T] he Welfare of Society will suffer immensely by such an unnatural convention. Many a child of the common man will of course be robbed of his natural Feeder, many a marriage, many a family will become more or less disordered, among the lesser as well as the higher classes.'

From Vaderlandsch A-B Boek voor de Nederlandsche jeugd (translation 'National AB book for the Dutch youth') (1781) ${ }^{1}$

The level and development of women's labour force participation in the nineteenth and twentieth centuries is a central theme in economic historical research. The outcomes of this research have wide-ranging implications for our understanding and interpretation of contemporaneous social processes, such as changing gender inequality in the division of household labour ${ }^{2}$ but they can also help us understand the growth experiences of countries as the withdrawal of women from the labour market can significantly affect the growth of the labour force. Understanding the division of household labour is, however, hampered by the fact that the historical literature on this topic consists of a diffuse set of stories. To some extent this is understandable and, as some claim, it is desirable. ${ }^{3}$ Whoever entertains thoughts on the withdrawal of women from the labour market in the nineteenth century and hence the rise of the housewife has come to grips not only with the economic, and often traceable factors that come into play in making choices, but also with social and other, more hidden, forces. In societies where class awareness and class distinctions were prominent one cannot ignore the role played by social norms and social roles. De Vries offers a challenging picture of modern economic growth and what might have driven the withdrawal of women from the labour market during the nineteenth century. Central to his explanation is a shift in preferences that gave greater weight to household products associated with hygiene, nutrition and the health and wealth of children at the expense of market products. ${ }^{4}$ 'Preference' is, however, too abstract a term to be of use in understanding family history. As Sunstein states 'preferences are constructed, rather than elicited, by social situations, in the sense that they are very much a function of the setting and the prevailing norms'. The quote at the top of this page is an example of a norm that affects the division of labour. It seeks to imbue 
Dutch youth with the values of being a good mother to Dutch youth at the close of the eighteenth century. The authors of this little booklet even involve God and the nation's welfare in choices about childcare. Women should preferably stay at home and care for and feed their children. ${ }^{6}$

The present study tries to make the tacit element in choices - the preference switch to which De Vries refers - more explicit and focuses on the emergence of the housewife in the Netherlands in the period 1812-1922. We will do so with the aid of marriage certificates. The story that unfolds is that the choice of women to withdraw from the labour market upon marriage is the result of three forces: (1) the intrinsic value of household 'products' (health, domesticity, schooling of children); (2) the reputational costs and benefits linked to becoming a housewife; and (3) the effects of choice on one's self-conception, or as Kuran would call it 'expressive utility'?

The intrinsic value of household production offers the core rationale for the social beliefs about how health and human wealth are created within the household and how labour should be divided. One reason given for women to stay at home was that it was the right thing to do for a mother. What makes our story so remarkable is that women withdrew from the labour market before children were born. This would suggest that the choice of entering marriage as a housewife was driven primarily by social norms.

Social norms - the second factor - operate as taxes and subsidies of individual choice and appear in many guises, such as laws, rules of conduct, wage discrimination and subsidies, working conditions, dismissal of women who become pregnant or pregnancy leave without pay, stereotyping, etc. The list of instruments to penalise the efforts of married women to accept work is long and diverse.

The third factor is closely related to the presence of norms. For example, a bride may choose to state no occupation in order to show her social environment that she intends to be 'a housewife'. The same may apply if the groom is the one who makes the choice. Making labour/leisure choices in this manner also covers the pursuit of so-called 'conspicuous leisure', a term used by Thorstein Veblen in his satirical description of the society of his day in his classic The theory of the leisure class. In a nutshell, Veblen contended that individual utility preferences can only be understood in relation to the utility preferences of upper-class others. Social classes competitively emulate the social strata above them and in doing so strengthen their own self-conceptions by demanding more social esteem. ${ }^{8}$ Singling out the force of 
expressive utility is difficult but we believe our data source may be particularly suited to dealing with this problem of self-conception. First of all, the day of marriage is an excellent testing ground for expressive utility because the promise 'until death do us part' is an ideal opportunity to show the world who one is, or rather to which group one aspires to belong. Secondly, as marriage certificates follow more or less uniform registration rules, they offer a consistent data source covering an extensive period of time and different places.

An inherent problem in disentangling the three forces is that the intrinsic value of household production is influenced by social beliefs, which in turn offer a rationalisation for adhering to the social norm of becoming a housewife. To identify the presence of norms is therefore a difficult if not impossible task as the interpretation of history is often a pluralistic exercise. A direct test is to see whether payment of a 'family wage', earned by the male breadwinner, was common practice. By subsidising the male breadwinner, women could stay at home. However, it is virtually impossible to disentangle the subsidy element from genuine wage, certainly across time and place. We are therefore looking for more indirect implications of the norm of the housewife. Naturally the upper classes could easily afford the norm of being a housewife. It is more puzzling, however, how the norm could spread over time and place among the lower classes. Here lies the possibility of really detecting the strength of social forces. We expect that the presence of social norms can be most clearly traced among working-class women for whom the household budget constraint was binding. To rephrase this, a true test of a social norm is that it is adhered to in spite of the fact that people cannot afford to live in accordance with such a norm. In particular, if a rise in withdrawal rates from the labour market by lower-class women outpaces the income growth rate of this particular class, social forces must be at work. The presence of cottage industries is another sign that social norms are prevalent. If the household income were sufficient one would not expect women to work in badly paid jobs and hazardous home environments. Indeed, due to the poor housing conditions, women and children were better off working in factories than in their own homes. ${ }^{9}$

Our depiction of the norm-driven emergence of the housewife and her mirror image - the male breadwinner - offers an encompassing view on the different perspectives on the division of labour within the household. There is a long line of family research, as summarised by Creighton ${ }^{10}$ in his overview of the rise of the male 
breadwinner family, a family type he defines as 'a particular model of household organization in which the husband is the sole agent operating within the market sector, deploying his labour in order to secure the funds necessary to support a dependent wife and children.' As the attention is often restricted to the position of women in the household and their withdrawal from the labour market we would like to focus on the housewife rather than on the more common male breadwinner. Social and family historians tend to describe the rise of the housewife in terms of the emergence of the cult of domesticity and the values associated with it. Under this domestic regime, it became inappropriate for women to work outside the home. ${ }^{11}$ According to Creighton ${ }^{12}$ much of the discussion is set in a Marxist frame of mind, where the division of labour is the outcome of historical struggles between social classes $^{13}$ or genders. ${ }^{14}$ His criticism focuses on a number of blind spots in the literature: an excessive emphasis on a restricted set of explanations based on a limited number of individual accounts; heavy emphasis on the working class at the expense of the role of employers; insufficient attention to the set of constraints and choices open to working class men and women; neglect of the interaction between the labour market and the household; and last but not least neglect of regional, sector and international differences in the diffusion of the housewife norm.

We take the criticism of Creighton to heart, but we also acknowledge that in order to examine the historical diffusion of social norms, historians must use data sources that give a consistent description over time and place but that also cover an extensive period of time to capture the essence of a phenomenon. In matters of population, health timing and specificity are key elements thereby making the use of long-run data not only desirable but necessary. ${ }^{15}$ The present empirical study sheds light on the emergence of the housewife and its strength relies on one particular data source - marriage certificates - that covers the experience of different regions and social classes during 110 years of Dutch history. Marriage certificates are a useful addition to the information from other sources and can be used to construct quantitative measures of the occupations of women in a historical perspective. We are not the first to use marriage certificates to study the division of labour within the household. Using data from the '3000 Families' Survey' for France, Motte and Pelissier studied the labour force participation of 13,500 brides who married in nineteenth-century France ${ }^{16}$, and Walker used evidence from marriage registers in South Yorkshire to check the occupation of women in the census period. ${ }^{17}$ Matthijs ${ }^{18}$ 
and Walhout and Van Poppel ${ }^{19}$ did the same for nineteenth century Louvain (Belgium) and a sample of Dutch municipalities respectively. The scale of the present study, however, is incomparable with those of earlier studies: the database covers six of the eleven Dutch provinces. These provinces differ markedly in terms of economic development and level of urbanisation and the total database covers 35 percent of all marriages registered in the Netherlands in the period 1812-1922.

The structure of this paper is straightforward. First we will present some background information on the Netherlands and its regional and sector structure. Second, the marriage certificates are introduced as a data source to track the division of labour within the household over time. Third, the occupational classification system is introduced and briefly discussed as this system is central to testing whether there are social class differences in the withdrawal of women from the labour market. Further information is added by taking a look at the data provided by the marriage certificates. These statistics are presented in Section IV, followed in Section V by logistic regression analysis explaining the probability that women will adhere to the social norm of entering marriage as a housewife. Section VI deals with the question whether labour choices in various classes and provinces converged across time and place. Section VII presents our conclusions and puts the research findings in perspective.

Much of the work on the development of the housewife relies heavily on British evidence, at the expense of other countries in Europe. ${ }^{20}$ There are sufficient indications that it is not possible to generalise from the British experience when discussing other European countries. For instance, Creighton claims that the male breadwinner model was first established among the middle classes, spreading widely among the working classes from the middle of the nineteenth century. Why this norm was first established among the middle classes remains somewhat of a mystery. Horrell and Humphries argued that a 'systematic empirical investigation of the male breadwinner family has been lacking' and that 'even the time-scale of its appearance and development remains obscure'. ${ }^{21}$ Horrell and Humphries and Janssens stress the need for studies on the precise historical and regional development in the division of household labour, covering strategically chosen periods, geographical areas, 
economic sectors and social groups. In this respect the Dutch case study may offer some interesting material on four counts.

Firstly, the Industrial Revolution took off relatively late in the Netherlands ${ }^{22}$ and the timing may be closely related to the way the Industrious Revolution ${ }^{23}$ emerged and evolved: a transformation of society from the mid-seventeenth century to the early nineteenth century in which leisure time was reduced and a reallocation took place of home-made goods and services for direct consumption to marketed goods. In the nineteenth century, the female labour effort in most countries turned away from the market production process and switched to household production. The integration of the household and market economies into one analytical model, as envisioned by De Vries, opens up an entirely new set of research questions as it necessitates the precise dating of the transformation, in the case of the present study the emergence of the housewife. The decline in growth of the labour force may have hampered economic growth, and this connection may help us understand why a country such as the Netherlands lagged behind the industrial leader of that time, the United Kingdom. To offer some background information, Table 1 offers a long-term picture of the wealth of European nations over the period 1500-1920.

Table 1. Per capita GDP in Western Europe, 1500-1920 (in 1990 international Geary-Khamis dollars)

\begin{tabular}{lcccccccc}
\hline & $\mathbf{1 5 0 0}$ & $\mathbf{1 6 0 0}$ & $\mathbf{1 7 0 0}$ & $\mathbf{1 8 2 0}$ & $\mathbf{1 8 5 0}$ & $\mathbf{1 8 7 0}$ & $\mathbf{1 9 0 0}$ & $\mathbf{1 9 2 0}$ \\
\cline { 2 - 8 } Austria & 707 & 837 & 993 & 1,218 & 1,650 & 1,863 & 2,882 & 2,412 \\
Belgium & 875 & 976 & 1,144 & 1,319 & 1,847 & 2,692 & 3,731 & 3,962 \\
Denmark & 738 & 875 & 1,039 & 1,274 & 1,767 & 2,003 & 3,017 & 3,992 \\
Finland & 453 & 538 & 638 & 781 & 911 & 1,140 & 1,668 & 1,846 \\
France & 727 & 841 & 910 & 1,135 & 1,597 & 1,876 & 2,876 & 3,227 \\
Germany & 688 & 791 & 910 & 1,077 & 1,428 & 1,839 & 2,985 & 2,796 \\
Italy & 1,100 & 1,100 & 1,100 & 1,117 & 1,350 & 1,499 & 1,785 & 2,587 \\
The Netherlands & 761 & 1,381 & 2,130 & 1,838 & 2,371 & 2,757 & 3,424 & 4,220 \\
Norway & 610 & 665 & 722 & 801 & 956 & 1,360 & 1,877 & 2,739 \\
Sweden & 695 & 824 & 977 & 1,198 & 1,289 & 1,662 & 2,561 & 2,802 \\
Switzerland & 632 & 750 & 890 & 1,090 & 1,488 & 2,102 & 3,833 & 4,314 \\
United Kingdom & 714 & 974 & 1,250 & 1,706 & 2,330 & 3,190 & 4,492 & 4,548 \\
Total 12 Western Europe & $\mathbf{7 9 8}$ & $\mathbf{9 0 7}$ & $\mathbf{1 , 0 3 2}$ & $\mathbf{1 , 2 4 3}$ & $\mathbf{1 , 6 5 8}$ & $\mathbf{2 , 0 8 7}$ & $\mathbf{3 , 0 7 6}$ & $\mathbf{3 , 3 0 4}$ \\
\hline
\end{tabular}

Source: Maddison (2004), http://www.ggdc.net/maddison/

The Dutch Republic was the dominant nation in the world of finance, trade and transport in the seventeenth century and this is clearly reflected in the income figures 
for this period. In the eighteenth century the dominant position was lost and from 1781 to 1813 the Netherlands underwent a transition from a decentralised state to a centralised nation state, during which the per capita income dropped. During the nineteenth century the British benefited from the Industrial Revolution and surpassed the still high income level in the Netherlands. By the year 1900, the per capita income in Belgium, Switzerland and the United Kingdom had surpassed the Dutch level, although the Dutch had by that time started catching up with technology leaders. As a result, the income level of the Dutch, expressed as GDP per capita, had also caught up with the levels found in Switzerland and the UK.

Besides the question of pinpointing the start of this transition and its subsequent development, the deeper puzzle triggered by the analysis of De Vries is the question: what drove this switch? The logical answer would be that a rise in real wages offered women the possibility of withdrawing from the labour market. De Vries points to a change in preferences for home-produced 'goods'. However, as mentioned above, labelling something as a 'preference switch' does not enhance our understanding and we should dig deeper to understand the construction of preferences.

A second reason why the Dutch case may prove instructive is the rich and diverse testing ground. The regions selected in this study - Groningen, Gelderland, Holland, Zeeland, Limburg and Overijssel - have a highly diverse socio-economic structure, and large differences in family structure and family relations. A vast body of literature has been published on the differences in economic structure between the economic heartland, that is the (urban) part of the provinces of South and North Holland, the highly productive agricultural coastal provinces (Zeeland and Groningen) and the eastern and southern Netherlands, in our case the provinces of Limburg, Gelderland and Overijssel.

The highly urbanised western part of the country was the heart of the economy, where at least 80 percent of the population worked in industry and the service sector, while agriculture was a subordinate source of employment. Holland also had a highly specialised horticultural sector and a diverse service industry.

In Groningen and Zeeland, the economy was almost entirely dependent on agriculture, with large-scale and productive farms, producing specialised primary products. In Zeeland the towns of Middelburg and Vlissingen were the administrative and industrial centres. Part of the Zeeland population was involved in the fishing 
industry. The economy of the region started to change after 1900 when industrialisation took place. The Groningen peat districts became an area of important industrial development in the second half of the nineteenth century; industrial activities here were based mainly on agricultural products.

In the eastern and southern provinces, agriculture was the most important activity. From the end of the nineteenth century, coal mining became an important economic activity in Limburg. The capital city of Maastricht was the place where large-scale industries developed for the first time in the Netherlands. Peat-digging and fen reclamation were carried out in the northern part of the province of Overijssel. From 1860-1870, cotton-spinning, together with bleaching works and machine manufacturing became very prominent in the Twente district in the east of the province. Farms in the provinces of Overijssel, Gelderland and Limburg were much smaller, the infrastructure less well-developed and the productivity of land and labour in these inland regions was almost half that of the coastal provinces of Holland, Groningen and Zeeland. Wages of agricultural labour were much higher in the coastal provinces than further inland. To give an impression of regional wage differences for a day labourer: in 1819 the wage per day was 65 cents in Groningen, 54 cents in Overijssel, 48 cents in Gelderland, 80 cents in North Holland, 88 cents in South Holland, 86 cents in Zeeland and 49 cents in Limburg. ${ }^{24}$ In general, the provinces of Holland, Groningen and Zeeland had far more intensive contacts with the outside world through the well-developed transportation network, the seaports, and their highly market-oriented agricultural activities. In addition, the level of literacy differed considerably across the various provinces. Whereas in protestant regions such as Groningen and North Holland at least 80 percent of the brides could write their names in 1819, in the southern provinces of Limburg and North Brabant the literacy level was in the range of 60 percent. Religious and cultural factors played a major role in the literacy divide: whereas Protestants were firmly set on stimulating education, Catholics were more inclined to leave the working classes uneducated as this would not threaten the power of the ruling classes.

A third reason why the Dutch case may prove instructive is the fact that at the end of the nineteenth century some fundamental changes occurred in the social belief system, which certainly must have affected the division of labour within the household over time. The nineteenth-century shifts in the social and economic structure confronted society with a variety of new social problems and aggravated 
some existing ones: pauperism, the heavy burden on private and public charities, prostitution, overcrowding, lack of hygiene and sanitary facilities, increased alcohol consumption, etc. To counter these Dickensian problems, the upper classes opted for a civilising offensive in which progressives and conservatives alike recognised that marriage and the family were fundamental social institutions, and that social change or the maintenance of the prevailing social order could be achieved only by taking the family into account. In this 'civilising offensive', the necessity of changes in the division of labour between men and women and the need for improvement in domestic hygiene played a very important role. ${ }^{25}$ The domestic ideology fostered by the middle-class nineteenth-century family stressed the different spheres inhabited by men and women. Married women were expected to concentrate their energy, attention and labour on the home and the family, caring for their husbands and children and maintaining the household in a material sense. Legislation, partly reflecting the changes in norms and incomes, also contributed to the emergence of the housewife, although in actual practice, the statutory measures made a modest contribution. Such measures included the Child Labour Act of 1874, which put a ban on child labour (below the age of 12) in factories, and the Labour Act of 1889; an act which restricted the maximum number of working hours (11 hours) for women and children between ages 12 and 16, a ban on night shifts for women and the option for government to prohibit certain dangerous jobs. The social norm of becoming a housewife was certainly strengthened by views expounded by orthodox Protestant and Catholic political parties in the first decade of the twentieth century. Catholic and Protestant views on the family, sexuality and the position of men and women then started to determine local and national policies. For both Catholics and Protestants, the only proper place for a married woman was in the home, as a mother, housewife and spouse. From the beginning of the twentieth century, the government tried to enforce this ideal by attempting to restrict and to forbid all work by married women outside the home. Legislative proposals attempted to forbid married women from any form of employment in the public service and in factories because of the assumed adverse influence on the care of children and the household.

Even more important in this regard were the activities of the health reformers who tried to change social beliefs. ${ }^{26}$ In the late nineteenth century, the 'sanitary movement' accorded a major role to deficient household arrangements in the spread of serious diseases. They recognised voluntary reforms within the private sphere as one of 
the most direct and effective means of improving public health. At the end of the nineteenth century, there was growing concern about the high rate of infant mortality. The solutions advocated by Dutch campaigners were, without exception, directed at the mother. A reduction in infant deaths was expected to follow from the re-education of the mother, who would be persuaded not to work outside the home, to improve her domestic hygiene, and to bathe, clothe and tend to her infants properly. The mother was to be educated by means of supervision by the new and expanding health-care facilities directed at women and children: hospital facilities, maternity clinics, maternity and district-nursing services, gynaecological and birth-control clinics, and through propaganda, courses, books and pamphlets. ${ }^{27}$

Fourthly, as in the British case, the scant Dutch historical studies on female labour force participation offer a diverse set of stories. Some authors have suggested that in the more distant past the labour force participation of women in the Dutch Republic was higher than in the surrounding countries. The complex, urban and heterogeneous character of the country provided more economic and social space for women than in other European societies, thereby increasing working women's opportunities. ${ }^{28}$ This high level of urbanisation generated many non-agricultural activities and the urban labour market offered women more opportunities than the rural labour market. ${ }^{29}$ The dominant opinion, however, is that as early as in the era of the Dutch Republic the labour force participation of women in the Netherlands was much lower than in other countries. Pott-Buter ${ }^{30}$ and Plantenga ${ }^{31}$ argue that due to the high standard of living, the male breadwinner model was already firmly established as the dominant family ideal in seventeenth-century Dutch society, and that this family ideal was within the reach of large proportions of the population. Van Zanden and Van Riel also argue that the 'breadwinner model' had become relatively commonplace in the Netherlands long before the nineteenth century. 'Whenever it could be afforded, there was 'specialization' in the household; the wife concentrated on the reproductive activities, while the husband earned an income on the labour market or from his own business. ${ }^{32}$ According to Van Zanden and Van Riel, it was the increase in real wages after about 1870 that enabled the Dutch to bring ideals and reality more into line with each other. De Vries and Van der Woude suggested that the low rates of female labour force participation observed at the very beginning of the nineteenth century might be related to Dutch society's 'pioneering role in developing the very concept of middle-class domesticity'. ${ }^{33}$ In this crucible of gezelligheid 
('cosiness'), standards of domestic comfort rose higher and spread further down the social scale than elsewhere in Europe before the nineteenth century. ${ }^{34}$

In short, the controversy over the emergence of the housewife in the Netherlands is due largely to a lack of national data, in particular for the period before 1890. Only very crude, often local and scattered data are available before the last quarter of the nineteenth century, making it almost impossible to draw firm conclusions on where, when and why the housewife norm emerged and triumphed. The interaction of time, region and social class in the division of household labour can be studied with great difficulty with the commonly used census data. ${ }^{35}$ The focus in censuses on the predominant male pattern of economic activity provides inadequate coverage of the economic activity of women ${ }^{36}$. It should be stressed, however, that the level of underrecording still remains open. ${ }^{37}$ And with this lack of historical data in mind we turn to an alternative data source: marriage certificates.

\section{II}

At the individual level, marriage certificates in many countries offer information on the occupation of bride and groom. An official marriage registration system was institutionalised in many countries of Europe as early as at the beginning of the nineteenth century. On the whole, marriage registration started well before occupational censuses were introduced thereby offering an alternative data source on the occupational distribution of a population. As marriage certificates in many countries contained more or less the same kind of information about the couple, international comparison of the occupational distribution of women over a long period of time is possible. In principle, marriage registration covered all marrying women at a crucial point in their life course. One of the most important advantages is that the certificate also contains information on the occupation of the husband. This allows us to study how class differences matter in the division of labour within the household. It is tempting to relate the marriage certificate information to the labour force participation of women. In the remainder of this study we will interpret the occupation women state on the marriage certificates as a reflection of their actual labour force participation. However, we do not have information on actual labour market participation before or after marriage and it would therefore be closer to the truth to view the information on the marriage certificate as reflecting the choice couples make 
in opting for either the dual breadwinner model or sole male breadwinning. ${ }^{38}$ Naturally, the choice to enter marriage as a housewife impinges on labour force participation rates but it is a snapshot impression of labour market behaviour. The real value of the marriage certificate information lies in the telltale signs it provides to explain the diffusion of a social norm. A wedding day is an important life event and signing a contract in front of family and officials is a social force that is bound to affect individual choices.

Of course, these data also have their shortcomings. An important question is whether the registered information on the occupation of the bride is reliable and valid. The legal provisions on this point, as laid down in successive Civil Codes, were clear. After the incorporation of the Netherlands into the French Empire, the Code Napoleon took effect in the Netherlands on 1 March 1811. Article 76 of the Code Napoleon stated that the marriage certificate had to make mention of the occupations of both spouses, as well as those of their parents and four witnesses. After the Netherlands had gained independence, the Code Napoleon remained in force until 1838, when a Dutch Civil Code came into effect. Article 45 of this Civil Code was heavily inspired by the Code Napoleon and included comparable rules regarding the form and contents of the marriage certificate. ${ }^{39}$ In the Parliamentary deliberations on the various drafts of the new Civil Code in the 1820s and 1830s, the question whether or not the occupation of the parties concerned had to be mentioned on the certificate was repeatedly discussed. It was eventually decided to hold onto the principle to include the occupation on the marriage certificate. The registration officer had to make mention of the occupation if the 'parties' concerned wished to do so. ${ }^{40}$

During the nineteenth and twentieth centuries various manuals were published, detailing instructions for registration officers on how to draw up marriage certificates. None of these manuals elaborated on extraordinary situations such as women who practised more than one occupation or who worked in a family business. ${ }^{41}$ The " 1936 Guide to vital statistics' was the first to include more detailed guidelines for registration officers on how to register the occupations of women. ${ }^{42}$ As a rule, it was argued, the marriage certificate had to make mention of 'the occupation of the woman when entering a marriage, or the job from which she resigned at the time of marriage or some time before in view of her prospective marriage'.

The occupational titles are self-reported titles and were given by the men and women themselves at the time the certificate was drawn up. Especially the fact that 
women state their own occupation gives marriage certificates a competitive edge over census data as it made registrations by marriage registrars less biased than those of census enumerators. In many cases the elaborateness and variety of the occupational titles mentioned by the couple suggest that husband and wife were aware of the fact that in doing so they were making a statement about their position in the local community. They took care to make clear that they were not just a weaver, for example, but a woollen weaver or a cotton weaver. The parties concerned were aware of the dignity of their occupational position, embodied in their qualifications and skills. In rural and small communities the public announcement of an intended marriage affected the way in which bride and groom answered the registration officer's questions about their occupation. The public image of themselves that individuals wanted to create is reflected in the details given or in the vagueness of the occupational titles. $^{43}$

Using marriage records is a time-consuming activity, and constraints of time and money necessitated researchers to focus on small communities and restricted time periods. During the past decade, however, several dozen volunteers and staff in various places in the Netherlands have started to enter marriage records into a database within the framework of the so-called GENLIAS-project. ${ }^{44}$ Only the essential data needed to reconstruct a family tree are added to the database. The marriage records provide information on the date and place of marriage, the names and ages of the bride and groom, the names of the bride's and the groom's parents, the places of birth of the bride and groom, the marital status of bride and groom, the occupation of bride and groom and in cases where the parents were alive, their occupation as well.

Complete data sets could be used for five of the eleven Dutch provinces: Gelderland, Groningen, Zeeland, Limburg and Overijssel. In addition, we were able to use a smaller dataset with information on marriages contracted in eight municipalities in the provinces of North and South Holland, the core region of the Netherlands. This is a heavily urban-biased sample that does not stretch as far in time as the other data sets. The database can provide a fairly accurate description of Dutch marriages because the data set relates to 35 percent of all marriages contracted in the Netherlands in the period 1822-1922. This coverage rate is more or less constant over the sample period. The total sample was fairly evenly distributed over the provinces, except for the sample for the province of Holland, which makes up less than 3.6 
percent of the total. Two-thirds of all marriages were contracted by women aged between twenty and thirty years old, and around 13 percent of the sample had contracted a second or third marriage. Women living in rural areas at the time of marriage dominate the sample. ${ }^{45}$

\section{III}

Social class is thought to be an essential factor in the story of the rise of the housewife. For a comparative study, statements of male and female occupations have to be consistent over time and place. A classification system is therefore needed that allows us to classify all occupations in a system that is applicable for the whole period and for both sexes. Such a system has to accommodate historical occupations such as lamplighters and barrel-makers as well as modern ones such as film directors and electronic engineers. We followed a coding and classification approach to occupational data based on a recently developed coding scheme called the Historical International Standard Classification of Occupations (HISCO) ${ }^{46}$, which translates occupational descriptions covering a long historical time, various languages and countries in a common code, compatible with the International Labour Organisation's International Standard Classification of Occupations (ISCO68) scheme.

In a second stage these historical occupational titles were classified into a social class scheme recently proposed by Van Leeuwen and Maas. ${ }^{47}$ Their classification scheme links HISCO codes to the so-called Dictionary of Occupational Titles, a classification system in which, for more than 35 thousand occupational titles, information is given on the nature of work (working conditions, work performed and industry), and the demands of the work in terms of training time, aptitudes, interests, temperaments and physical demands. The characteristics of the HISCO codes, as presented in the Dictionary of Occupational Titles, were then classified by experts into 12 classes, cross-validated with other class schemes, and their predictive validity was tested. Twelve classes are distinguished: higher managers, higher professionals, lower managers, lower professionals and clerical and sales personnel, lower clerical and sales personnel, foremen, skilled workers, farmers, lower-skilled workers, lowerskilled farm workers, unskilled workers and finally unskilled farm workers. ${ }^{48}$ 
The class distinction in the emergence of the housewife is clearly revealed in some detail in Table 2. To determine the employment status of the wife at the time of marriage we compared the total number of women marrying at a given point in time with the number of women classified in one of these twelve categories. Among women classified as 'working', we also included those who had an occupation at the time of marriage that could not be classified because of the fact that occupational information in the marriage certificate was so vague that it was unclear what the title meant or because the title referred to a multitude of possible occupational activities. Women classified as 'not working' mainly consisted of women for whom the occupational entry explicitly stated that they had no work ('without occupation'). In the province of Overijssel the occupational entry in the database was left blank for all women for whom no occupational title was given at the time of marriage. In all regions there were marriage certificates in which the occupational entry contained information that did not relate directly to a job, including terms such as 'pauper', 'student', or a person of private means ('rentenier'). All three categories were included among non-working women. In a considerable number of cases, the wife or daughter of a farmer was described as a 'farmer's wife' or 'farmer's daughter'. Whether these descriptions were intended to indicate the occupation of these women or simply their relationship to the head of household cannot be determined. ${ }^{49} \mathrm{We}$ included them among the non-working women.

A number of observations can be distilled from Table 2. From the first decades of the nineteenth century, only a negligible percentage of women in the two highest social classes (higher managers and professionals), still had a job at the time of marriage. Around the turn of the century almost all women marrying a husband from the highest social class had stopped working at the time of marriage. After 1910 a slight increase in women's labour force participation took place. The groups of lowerskilled and unskilled workers in and outside the agricultural sector had by far the highest percentages of working women, and the decline in labour fore participation over time was slower and less abrupt here than in any other social class. 
Table 2. Percentage of women with no occupation at the time of marriage, by social class of husband and period of marriage

\begin{tabular}{|c|c|c|c|c|c|c|c|c|c|c|c|c|}
\hline $\begin{array}{l}\text { Period of } \\
\text { marriage }\end{array}$ & $\begin{array}{c}\text { Higher } \\
\text { managers }\end{array}$ & $\begin{array}{c}\text { Higher } \\
\text { professionals }\end{array}$ & $\begin{array}{c}\text { Lower } \\
\text { managers }\end{array}$ & $\begin{array}{c}\text { Lower } \\
\text { professional } \\
\text { and clerical, } \\
\text { sales }\end{array}$ & $\begin{array}{c}\text { Lower } \\
\text { clerical } \\
\text { and sales }\end{array}$ & $\begin{array}{c}\text { Skilled } \\
\text { workers }\end{array}$ & Foremen & $\begin{array}{c}\text { Lower- } \\
\text { skilled } \\
\text { workers }\end{array}$ & $\begin{array}{c}\text { Unskilled } \\
\text { workers }\end{array}$ & Farmers & $\begin{array}{l}\text { Lower- } \\
\text { skilled } \\
\text { farm } \\
\text { workers }\end{array}$ & $\begin{array}{c}\text { Unskilled } \\
\text { farm } \\
\text { workers }\end{array}$ \\
\hline $1812-19$ & 90.5 & 93.3 & 64.8 & 67.4 & 71.3 & 50.5 & 36.5 & 20.0 & 38.1 & 47.5 & 23.7 & 29.2 \\
\hline $1820-29$ & 91.2 & 94.8 & 63.6 & 68.8 & 70.3 & 50.4 & 32.7 & 19.7 & 37.8 & 47.0 & 20.3 & 24.8 \\
\hline $1830-39$ & 92.2 & 96.5 & 65.6 & 68.8 & 67.1 & 51.8 & 42.4 & 22.1 & 39.1 & 46.6 & 23.4 & 23.0 \\
\hline $1840-49$ & 91.7 & 96.8 & 65.7 & 70.1 & 67.1 & 57.0 & 35.9 & 22.1 & 41.0 & 52.4 & 27.8 & 28.0 \\
\hline $1850-59$ & 92.5 & 94.6 & 70.1 & 72.0 & 67.2 & 58.4 & 28.7 & 23.8 & 41.7 & 56.7 & 31.1 & 28.8 \\
\hline $1860-69$ & 94.4 & 97.1 & 74.6 & 72.5 & 75.1 & 62.1 & 24.3 & 26.0 & 45.5 & 62.2 & 31.4 & 31.9 \\
\hline $1870-79$ & 95.8 & 97.6 & 80.2 & 78.1 & 77.0 & 66.8 & 25.2 & 29.3 & 47.4 & 68.0 & 42.1 & 36.6 \\
\hline $1880-89$ & 96.3 & 97.5 & 81.4 & 81.3 & 79.4 & 69.4 & 26.2 & 32.3 & 54.4 & 73.7 & 52.6 & 42.6 \\
\hline $1890-99$ & 95.9 & 98.2 & 86.1 & 83.1 & 84.0 & 75.3 & 26.0 & 36.9 & 63.1 & 77.1 & 64.6 & 49.8 \\
\hline 1900-09 & 95.3 & 95.9 & 87.8 & 85.7 & 86.2 & 78.8 & 32.6 & 44.4 & 61.2 & 80.6 & 72.2 & 57.2 \\
\hline $1910-22$ & 92.2 & 90.2 & 89.4 & 84.0 & 86.9 & 81.1 & 43.7 & 54.3 & 60.2 & 86.1 & 78.9 & 66.7 \\
\hline
\end{tabular}

Source: GENLIAS and ISIS database 
For both lower-skilled and unskilled workers those employed in agriculture had considerably higher participation rates than those employed outside the agricultural sector. Until the middle of the nineteenth century, around three-quarters of women marrying an unskilled farm worker were still working at the time of marriage. Even in the first decades of the twentieth century, when more than four out of five women marrying in the high and middle social classes had given up work at the time of their marriage, as many as 35 to 45 percent of women marrying unskilled workers still had a job.

The social status of bride and groom is, of course, not the only piece of information provided on a marriage certificate. To resolve the puzzle of when and where 'the Dutch housewife' emerged, one can consult other information entered into the database. This is succinctly presented in Table 3. To study social class differences in the emergence of the housewife, some social class categories described in section III that contained too few cases were grouped together. In our analysis, lower managers, lower professionals and clerical and sales personnel, lower clerical and sales personnel and foremen were grouped in the category 'white-collar middle class'. Higher managers and higher professionals were grouped into the 'upper class' category; lower-skilled workers and lower-skilled farm workers were also grouped together. This resulted in seven categories: (1) Upper class (2) White-collar middle class (3) Skilled workers (4) Farmers (5) Lower-skilled workers (6) Unskilled workers and (7) Unskilled farm workers. Grooms for whom no occupation was given or for whom the occupational information was unclear were excluded from the analysis.

The distribution of spouses over social groups shows that a large majority of the grooms belonged to the working classes: low and unskilled workers made up 51 percent of all grooms, and skilled workers another 17 percent. One fifth of the grooms were farmers. The upper and middle classes made up 13 percent of the total. Note that the distribution of occupational classes across provinces is uneven. Table 4 gives an impression of how the distribution of classes differs across provinces. 
Table 3. Descriptive statistics

\begin{tabular}{|c|c|c|}
\hline & $\begin{array}{c}\text { Percentage of } \\
\text { sample for each } \\
\text { variable: }\end{array}$ & $\begin{array}{c}\text { Brides who did not } \\
\text { state an occupation } \\
(\%)\end{array}$ \\
\hline \multicolumn{3}{|l|}{ Status groom } \\
\hline Higher managers and higher professionals & 1.8 & 95.1 \\
\hline Lower managers, lower professional and clerical, sales, foremen & 10.8 & 82.8 \\
\hline Skilled workers & 17.3 & 68.9 \\
\hline Farmers & 19.1 & 70.6 \\
\hline Lower-skilled workers and lower-skilled farm workers & 12.8 & 64.1 \\
\hline Unskilled workers & 16.1 & 55.2 \\
\hline Unskilled farm workers & 22.1 & 41.8 \\
\hline \multicolumn{3}{|l|}{ Period of marriage } \\
\hline $1812-19$ & 4.0 & 45.0 \\
\hline $1820-29$ & 5.5 & 42.3 \\
\hline $1830-39$ & 6.1 & 42.8 \\
\hline $1840-49$ & 6.8 & 47.8 \\
\hline $1850-59$ & 8.0 & 50.2 \\
\hline $1860-69$ & 9.0 & 54.5 \\
\hline $1870-79$ & 9.7 & 59.9 \\
\hline $1880-89$ & 9.2 & 65.1 \\
\hline $1890-99$ & 10.7 & 70.6 \\
\hline 1900-09 & 12.2 & 74.9 \\
\hline $1910-22$ & 19.0 & 79.5 \\
\hline \multicolumn{3}{|l|}{ Region } \\
\hline Zeeland & 14.6 & 46.3 \\
\hline Limburg & 16.1 & 60.7 \\
\hline Overijssel & 20.7 & 64.3 \\
\hline Holland & 3.6 & 77.8 \\
\hline Gelderland & 27.3 & 68.9 \\
\hline Groningen & 17.7 & 61.8 \\
\hline \multicolumn{3}{|l|}{ Place of residence } \\
\hline Rural & 64.1 & 59.0 \\
\hline Urban & 35.9 & 68.5 \\
\hline \multicolumn{3}{|l|}{ First marriage/Remarriage } \\
\hline First marriage & 86.9 & 63.8 \\
\hline Remarriage & 13.1 & .8 \\
\hline \multicolumn{3}{|l|}{ Age at marriage } \\
\hline $14-19$ & 6.5 & 70.0 \\
\hline $20-24$ & 39.0 & 65.2 \\
\hline $25-29$ & 30.5 & 62.1 \\
\hline $30-34$ & 12.7 & 58.9 \\
\hline $35-39$ & 5.4 & 55.2 \\
\hline $40-44$ & 2.8 & 53.2 \\
\hline $45+$ & 3.1 & 56.2 \\
\hline Total sample & \multicolumn{2}{|c|}{$1,016,573$} \\
\hline
\end{tabular}

Source: GENLIAS and ISIS database 
Table 4. Regional divergence in social classes of grooms

\begin{tabular}{lcccccc}
\hline Social class: & Zeeland & Limburg & Overijssel & Holland & Gelderland & Groningen \\
\hline Upper class & 1.4 & 1.8 & 1.6 & 3.2 & 1.9 & 2.1 \\
White-collar middle class & 10.2 & 9.7 & 9.6 & 17.1 & 10.8 & 12.4 \\
Skilled workers & 14.2 & 18.6 & 16.0 & 23.7 & 17.4 & 18.6 \\
Farmers & 9.5 & 27.0 & 25.8 & 6.6 & 20.9 & 11.7 \\
Lower-skilled workers $^{\mathrm{a}}$ & 8.3 & 16.7 & 13.9 & 19.4 & 14.1 & 8.6 \\
Unskilled farm workers $_{\text {Unskilled workers }}^{40.6}$ & 10.2 & 14.1 & 5.8 & 21.9 & 30.5 \\
Total & 15.7 & 16.2 & 19.0 & 24.3 & 13.1 & 16.2 \\
$\mathrm{~N}=$ & 100 & 100 & 100 & 100 & 100 & 100 \\
\hline
\end{tabular}

(a) Including farm workers.

Source: GENLIAS and ISIS database

Holland is clearly the most developed of the provinces and the Holland sample contains a relatively large number of grooms of the higher echelons of society. Of course, this bias is the result of the fact that the sample for this particular province consists of marriages contracted in cities. The other provinces are more balanced, but they too show some clear differences. The percentage of farmers in particular is relatively high (21-27 percent) in Limburg, Overijssel, and to a lesser extent Gelderland, and in Groningen and Zeeland the percentage of farmers is around 10 percent. Much of this difference is a result of the scale of farming. Limburg, Overijssel and Gelderland are regions where small-scale farming dominated at the time. In connection with this development, it is understandable that provinces that had large-scale farming are also the provinces where large numbers of (unskilled) farm workers found employment.

Figure 1 shows the development of the percentage of housewives by period of marriage and region. In the first half of the nineteenth century, withdrawal rates in the various provinces - with the exception of Overijssel - were still rather stable. An increase in withdrawal from the labour market is visible from the second half of the nineteenth century. ${ }^{50}$ The overall tendency is therefore one of a rise to dominance of the housewife within the household.

The specific regions may cover up differences in urbanisation. In each province we classified municipalities into urban or rural ones with the aid of information on the number of inhabitants, population density, the percentage of the population working in agriculture in 1889 (approximately halfway the period) and on 
Figure 1. Emergence of the housewife across Dutch provinces (percentage of women without occupation at the time of marriage)

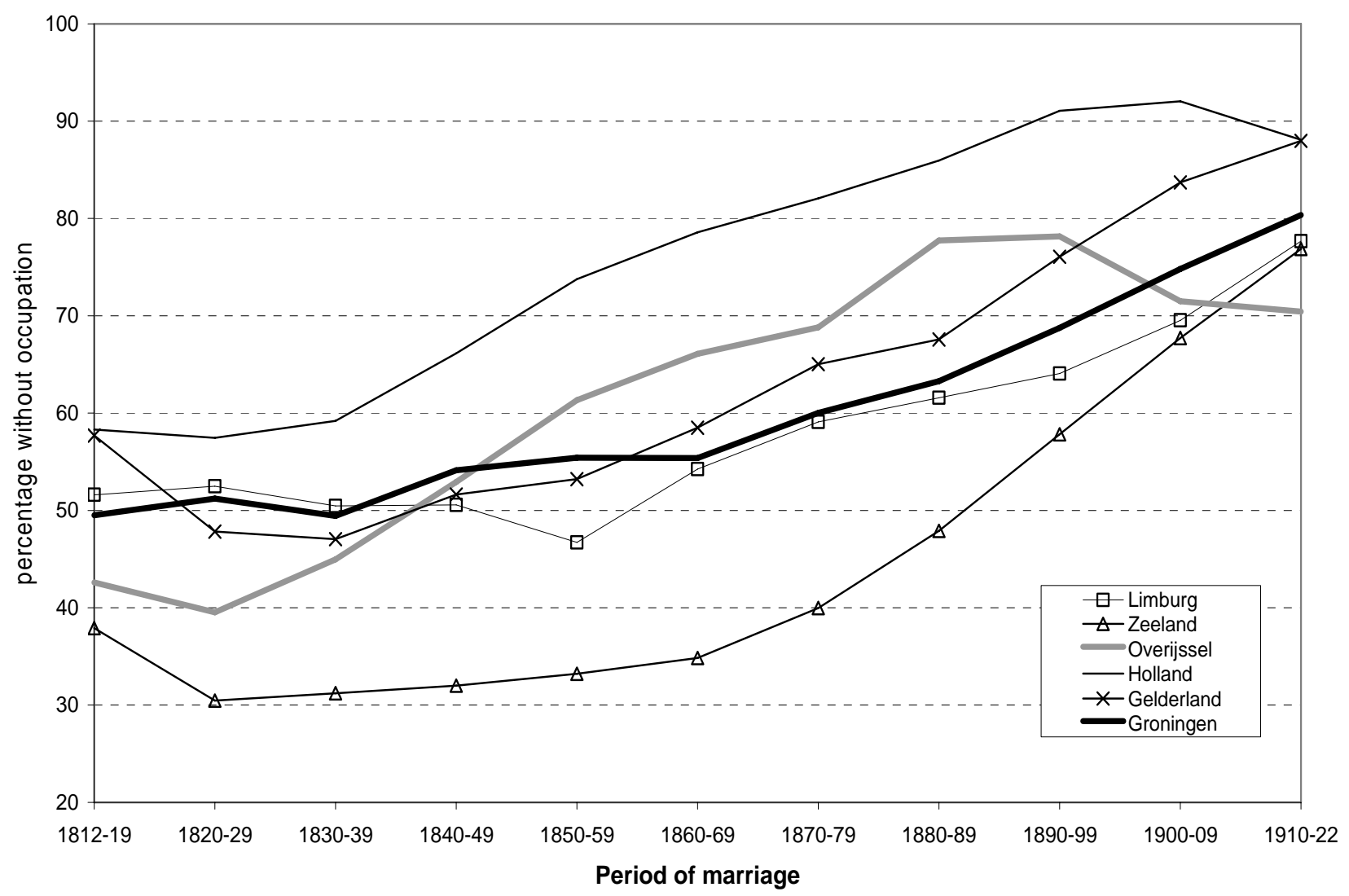

Source: GENLIAS and ISIS database

the historical designation of a municipality as a 'town' or 'village'. As one can deduce from Table 3, clear differences exist in labour market behaviour: the housewife is far more prominent in urban municipalities than in rural ones: 69 percent of urban brides did not mention an occupation against 59 percent of rural brides.

The statistics presented in the various tables and figures presented above still beg the question as to which factors exert an independent influence on the diffusion of the social norm that women enter marriage without a job. For instance, the fact that the 
province of Holland had more housewives than Limburg can be ascribed to the fact that Holland was a far wealthier province and a province with a more skilled labour force than Limburg. The question in which we are interested is to what extent the diffusion of the housewife-cum-male-breadwinner norm was affected by time, place and class. The central hypothesis to be tested is the null hypothesis that the division of labour within the household is affected by social norms. Controlling for wealth (approximated by social class), the factor time should matter if social norms play a role of importance. If there is no trend over time, the null hypothesis can be discarded. The factor 'place' (approximated by urban/rural status or province) is an ambiguous explanatory factor. It can designate wealth, as regions are endowed with different economic production possibilities and as economic geographers argue that urbanisation is often accompanied by economies of scale and scope, which rural sites lack. But regions and urbanisation levels could also signify or approximate a specific culture. ${ }^{51}$ In the remainder of this study we will not overemphasise the factor 'place' as an element that 'proves' the presence of social norm diffusion, but it remains a plausible possibility. Finally, each social class may cover up its own specific social norms, but in the absence of more information on the marriage certificate this hypothesis may help to interpret the regression results.

In Table 5 we present the logistic regression results of the probability that women stated 'no occupation' at the time of marriage. Odds ratios are presented to give an idea of the likelihood that at certain times, places or in certain social classes this norm is accepted and adhered to. To see whether differences exist between urban and rural areas we have estimated two sub-models (models II and III). The probability that brides said they had no occupation was regressed on the variables described earlier in Table 2. Differences between social classes in the degree to which women gave up working at the time of marriage were enormous. Compared with the wife of an unskilled farm worker, for example, wives in the upper classes were 24 times more likely to state 'no occupation' at the time of marriage and non-participation in the white-collar middle class was 5.3 times more likely compared with unskilled farm workers. The fact that social class differences exist is noteworthy but not the most interesting point shown in Table 5 . 
Table 5. Explaining the reporting of occupation by women on marriage certificates, the Netherlands $1812-1922^{\mathrm{a}}$

\begin{tabular}{|c|c|c|c|c|c|c|}
\hline & \multicolumn{6}{|c|}{$\begin{array}{l}\text { Probability of stating 'no occupation' by bride } \\
\text { (reporting of occupation }=0 \text { ) }\end{array}$} \\
\hline & \multicolumn{2}{|c|}{ Model I } & \multicolumn{2}{|c|}{ Model II } & \multicolumn{2}{|c|}{ Model III } \\
\hline & \multicolumn{2}{|c|}{ Total sample } & \multicolumn{2}{|c|}{ Urban } & \multicolumn{2}{|c|}{ Rural } \\
\hline & Odds & t-value & Odds & t-value & Odds & t-value \\
\hline \multicolumn{7}{|l|}{ Status groom (Unskilled farm workers $=1.00)$} \\
\hline Upper class & 24.42 & 91.81 & 29.89 & 63.33 & 18.68 & 60.07 \\
\hline White-collar middle class & 5.29 & 168.81 & 5.40 & 69.23 & 4.87 & 119.67 \\
\hline Skilled workers & 2.63 & 128.98 & 2.50 & 40.02 & 2.59 & 105.95 \\
\hline Farmers & 3.18 & 162.22 & 3.30 & 46.50 & 2.93 & 141.20 \\
\hline Lower-skilled workers and farm workers & 1.92 & 80.43 & 2.00 & 29.85 & 1.80 & 58.09 \\
\hline Unskilled workers & 1.44 & 48.67 & 1.39 & 14.63 & 1.32 & 29.55 \\
\hline \multicolumn{7}{|l|}{ Period of marriage $(1812-19=1.00)$} \\
\hline $1820-29$ & 0.92 & 5.79 & 1.00 & 0.14 & 0.88 & 7.66 \\
\hline $1830-39$ & 0.95 & 4.14 & 1.12 & 4.89 & 0.85 & 9.38 \\
\hline $1840-49$ & 1.17 & 11.48 & 1.39 & 14.49 & 1.06 & 3.29 \\
\hline $1850-59$ & 1.30 & 20.11 & 1.55 & 19.85 & 1.19 & 10.08 \\
\hline $1860-69$ & 1.53 & 33.23 & 1.79 & 26.58 & 1.42 & 22.18 \\
\hline $1870-79$ & 1.83 & 47.82 & 2.15 & 35.23 & 1.71 & 34.32 \\
\hline $1880-89$ & 2.22 & 62.20 & 2.65 & 44.16 & 2.07 & 45.85 \\
\hline $1890-99$ & 2.88 & 83.24 & 4.04 & 62.77 & 2.48 & 58.37 \\
\hline 1900-09 & 3.45 & 98.15 & 4.00 & 63.60 & 3.27 & 76.09 \\
\hline $1910-22$ & 4.24 & 119.00 & 4.08 & 68.39 & 4.54 & 99.95 \\
\hline \multicolumn{7}{|l|}{ Region (Zeeland $=1.00)$} \\
\hline Limburg & 1.35 & 37.14 & 0.71 & 23.62 & 1.87 & 63.40 \\
\hline Overijssel & 1.65 & 65.31 & 1.19 & 12.94 & 1.99 & 71.60 \\
\hline Holland (North and South Holland) & 3.69 & 89.29 & 2.72 & 54.48 & 4.93 & 53.24 \\
\hline Gelderland & 2.08 & 100.39 & 1.44 & 26.93 & 2.46 & 102.76 \\
\hline Groningen & 1.67 & 66.52 & 2.19 & 52.26 & 1.51 & 44.85 \\
\hline \multicolumn{7}{|l|}{ Rural place of residence $($ rural $=1.00)$} \\
\hline Urban & 1.13 & 22.10 & - & - & - & - \\
\hline \multicolumn{7}{|l|}{ Age at marriage $(14-19=1.00)$} \\
\hline $20-24$ & 0.75 & 27.15 & 0.71 & 18.66 & 0.76 & 21.83 \\
\hline $25-29$ & 0.65 & 40.81 & 0.59 & 28.49 & 0.65 & 33.25 \\
\hline $30-34$ & 0.60 & 43.93 & 0.55 & 29.56 & 0.59 & 37.05 \\
\hline $35-39$ & 0.55 & 44.47 & 0.49 & 29.93 & 0.54 & 36.84 \\
\hline $40-44$ & 0.53 & 39.16 & 0.50 & 24.99 & 0.51 & 33.21 \\
\hline $45+$ & 0.61 & 30.27 & 0.59 & 19.03 & 0.58 & 26.52 \\
\hline \multicolumn{7}{|l|}{ First-time marriage $($ remarriage $=1.00)$} \\
\hline First marriage & 1.15 & 18.01 & 1.00 & 0.13 & 1.23 & 21.58 \\
\hline $\mathrm{N}=$ & \multicolumn{2}{|c|}{$1,016,573$} & \multicolumn{2}{|c|}{364,759} & \multicolumn{2}{|c|}{651,814} \\
\hline Pseudo $\mathrm{R}^{2}$ & \multicolumn{2}{|c|}{0.13} & \multicolumn{2}{|c|}{0.11} & \multicolumn{2}{|c|}{0.13} \\
\hline
\end{tabular}

(a) Bold-faced coefficients are statistically significant at 1\% significance level.

The first factor - place - reveals large differences across provinces, and if we disaggregate the sample into an urban and a rural sample (models II and III) we see that there are substantial differences in household behaviour. To explain this geographical diversity, it is useful to turn to the large discrepancies in the economic 
structure of the regions that were so characteristic of the nineteenth and earlytwentieth century Netherlands. In the province of Holland, the economic and urban centre of the country where a large part of the population worked in the service sector, a relatively small number of women said they had an occupation at the time of marriage. In the first half of the nineteenth century the percentage of housewives here was ten to thirty percent higher than in other provinces. The high real wages that men could earn were sufficient to support a family, making it possible for women to occupy themselves with the household instead of doing paid work. Bourgeois family values may have permeated this province earlier and may have affected other social classes to a greater extent thanks to the existence of a wealthy and relatively large bourgeoisie. The percentage of housewives in the five, primarily agricultural provinces was much lower than in Holland. In the 'peripheral' eastern and southern provinces of Overijssel and Limburg a peasant structure characterised the agricultural economy, with small, non-specialized and self-supporting holdings. In peasant households, women traditionally had a strong, visible and hence undeniable role in family subsistence and commodity production. In the cottage industries, closely linked to agricultural activities, the family also acted as the production unit, and men, women and children were each responsible for specific parts of the production process. Real incomes were relatively low and the incomes of men usually insufficient to cover all family expenses. ${ }^{52}$ Female labour was therefore essential and very large numbers of women worked in agriculture, as was the case in Zeeland.

The second factor - time - is visible in the trend terms of the various models of Table 5: the differences between the first three periods were very small, and based on this model one is tempted to say that the rise of the housewife started in the 1840s. Estimates based on the sub-samples related to the level of urbanisation (models II and III) show that the housewife emerged far earlier in urban areas and that people living in rural areas lagged behind in adhering to the social norm by 10 to 20 years. Based on these more detailed models, we see that in urban regions the rise of the housewife started in the $1830 \mathrm{~s}$ and that in rural areas the rise began in the $1850 \mathrm{~s}$. It is only in the last decade of the sample, the 1910s, that the speed of diffusion in rural regions surpassed that of urban regions.

The previous results suggest that the emergence of the housewife was norm driven, but alternative explanations have to be considered to test the robustness of our findings. Using marriage certificates as the prime data source has its restrictions as it 
might give the impression that the strong increase in withdrawal rates of wives of lower-class workers coincided with a decrease in demand for this type of work. The withdrawal of women could be interpreted as a structural change in labour demand and not the result of a social norm. At the start of the twentieth century there was a slight decrease in the number of housewives among the upper classes and a strong increase in housewives among the lower-skilled classes (see Table 2).

Table 6. Census information on female employment in sectors of industry (as a percentage of employed in a sector). 1849-1920

\begin{tabular}{|c|c|c|c|c|c|c|}
\hline \multirow[t]{2}{*}{ Sector: } & 1849 & 1859 & 1889 & 1899 & 1909 & 1920 \\
\hline & \multicolumn{6}{|c|}{ Female employees as a percentage of total employed in a sector } \\
\hline Ceramics and glass & 9.1 & 8.3 & 10.3 & 9.3 & 8.9 & 6.6 \\
\hline Diamond cutting & 2.9 & 0.7 & 4.1 & 11.0 & 10.0 & 10.1 \\
\hline Printing & 1.3 & 0.8 & 0.6 & 1.1 & 2.5 & 6.0 \\
\hline Building \& construction & 0.3 & 0.3 & 0.3 & 0.4 & 0.3 & 0.1 \\
\hline Chemicals & 9.0 & 6.5 & 16.8 & 19.9 & 21.2 & 18.4 \\
\hline Woodworking & 1.9 & 2.8 & 1.4 & 2.2 & 2.4 & 2.7 \\
\hline Clothing \& cleaning & 58.3 & 54.9 & 55.9 & 60.2 & 63.6 & 63.1 \\
\hline Applied arts & 7.1 & 5.1 & 5.5 & 5.1 & 6.5 & 1.7 \\
\hline Leather & 1.5 & 1.5 & 1.7 & 3.5 & 4.9 & 7.5 \\
\hline Mining & 11.7 & 2.0 & 13.8 & 9.2 & 11.2 & 7.1 \\
\hline Metal \& shipbuilding & 1.3 & 0.9 & 0.9 & 1.4 & 2.2 & 3.9 \\
\hline Paper & 10.1 & 11.2 & 11.4 & 13.5 & 15.8 & 20.6 \\
\hline Textiles & 28.0 & 27.4 & 24.4 & 29.7 & 33.1 & 33.6 \\
\hline Utilities & 0.0 & 0.0 & 0.1 & 0.2 & 0.2 & 3.0 \\
\hline Food \& stimulants & 3.9 & 2.7 & 3.6 & 4.4 & 5.3 & 9.3 \\
\hline Agriculture & 34.9 & 33.4 & 27.5 & 26.2 & 26.0 & 14.1 \\
\hline Fishing & 0.4 & 0.3 & 0.4 & 2.5 & 0.3 & 1.6 \\
\hline Trade & 23.9 & 21.6 & 21.5 & 21.3 & 20.6 & 18.2 \\
\hline Catering industry & 29.6 & 25.7 & 24.4 & 29.9 & 37.8 & 25.3 \\
\hline Shipping & 0.8 & 0.8 & 1.0 & 1.1 & 1.0 & 1.4 \\
\hline Other transport & 3.8 & 2.3 & 3.1 & 2.8 & 3.3 & 2.8 \\
\hline Banking & 6.7 & 2.5 & 0.6 & 0.8 & 4.4 & 17.1 \\
\hline Insurance & 1.0 & 0.1 & 0.9 & 1.8 & 5.5 & 22.9 \\
\hline Public administration & 0.4 & 0.3 & 0.8 & 1.1 & 1.6 & 11.6 \\
\hline Military & 0.0 & 0.0 & 0.0 & 0.0 & 0.0 & 0.0 \\
\hline Medical service & 28.3 & 26.9 & 54.8 & 62.3 & 69.8 & 72.3 \\
\hline Education & 20.3 & 20.6 & 35.4 & 41.8 & 49.4 & 51.9 \\
\hline Domestic service & 89.0 & 88.5 & 93.2 & 96.0 & 96.0 & 95.6 \\
\hline Labourers & 2.3 & 2.9 & 2.1 & 0.3 & 0.1 & 0.1 \\
\hline Religion & 4.8 & 2.8 & 13.9 & 8.9 & 5.7 & 26.5 \\
\hline TOTAL & 28.8 & 26.9 & 25.5 & 25.9 & 25.9 & 23.1 \\
\hline
\end{tabular}

Source: Statistics Netherlands, http://www.volkstellingen.nl/en/ 
This suggests that a structural change might have occurred. Supplementary statistics on female labour force participation are provided by various censuses (see Table 6) and these data offer some confirmation that the same trends can be observed. Certain sectors have always been the traditional domain of women, such as clothing and cleaning, textiles, catering, farm work and of course domestic services, and this type of work was typically low-skilled. The censuses also show that from the end of the nineteenth century a counter movement developed. Economic developments after 1870 led to the creation of new female occupational groups and a rapid increase in the demand for educated workers - office clerks, bookkeepers, secretaries, teachers and civil servants. In this process women gained access to new types of jobs, for example in education, health care, banking, insurance and public administration. The importance of these developments should not be overrated, however. The labour force participation of women was low and the percentage of higher skilled women within this group was extremely small. By and large, most women worked in agriculture and domestic services. The same picture appears if we take a look at the skill structure of 'working wives' in our database, i.e. brides who did report an occupation (see Table 7).

Table 7: Skill level of occupations of 'working women' (i.e. brides who reported an occupation), 1812-1922

\begin{tabular}{lccccccc}
\hline \multicolumn{7}{c}{ Type of occupation: } \\
\hline Period: & $\begin{array}{c}\text { Upper } \\
\text { class }\end{array}$ & $\begin{array}{c}\text { Middle } \\
\text { class }\end{array}$ & $\begin{array}{c}\text { Skilled } \\
\text { workers }\end{array}$ & Farmers & $\begin{array}{c}\text { Lower- } \\
\text { skilled } \\
\text { workers }\end{array}$ & $\begin{array}{c}\text { Unskilled } \\
\text { workers }\end{array}$ & $\begin{array}{c}\text { Unskilled } \\
\text { farm } \\
\text { workers }\end{array}$ \\
\hline $1812-19$ & 0.2 & 4.4 & 13.8 & 20.7 & 10.7 & 16.6 & 33.7 \\
$1820-29$ & 0.2 & 3.9 & 13.0 & 16.2 & 11.4 & 18.1 & 37.3 \\
$1830-39$ & 0.2 & 3.9 & 13.6 & 16.2 & 11.5 & 17.2 & 37.5 \\
$1840-49$ & 0.2 & 3.9 & 14.1 & 15.6 & 11.5 & 18.5 & 36.3 \\
$1850-59$ & 0.2 & 3.7 & 13.6 & 14.9 & 11.3 & 19.0 & 37.3 \\
$1860-69$ & 0.2 & 3.9 & 13.4 & 14.7 & 10.2 & 19.4 & 38.2 \\
$1870-79$ & 0.2 & 4.5 & 14.1 & 14.1 & 10.4 & 19.4 & 37.2 \\
$1880-89$ & 0.2 & 5.0 & 16.1 & 12.8 & 12.2 & 18.4 & 35.4 \\
$1890-99$ & 0.2 & 5.7 & 15.0 & 12.9 & 13.5 & 18.2 & 34.6 \\
$1900-09$ & 0.3 & 6.3 & 15.7 & 12.7 & 15.0 & 21.6 & 28.4 \\
$1910-22$ & 0.7 & 9.4 & 16.2 & 11.4 & 18.5 & 23.3 & 20.5 \\
\hline
\end{tabular}

Source: GENLIAS and ISIS database

The type of jobs of working women clearly seems to have been upgraded during the period of observation. At the start of the nineteenth century, 19 percent of the wives were trained in skilled jobs. By the 1910s this percentage had increased to 26 percent. 
The upgrading trend is ambiguous, however, because, as shown in Table 7 , the number of lower-skilled and unskilled working women had also increased over time.

There is some ground to believe that another structural change took place, a development closely connected to the increasing mechanisation of household production, which offered higher-class households the opportunity to substitute capital for labour. In order to keep houses clean and pay attention to proper nutrition, standards of household work rose over time. This could initially be met by hiring more servants. The development of the percentage of domestic servants among brides (see Figure 2) - the most often named occupation - may reflect this trend. Starting in the $1860 \mathrm{~s}$, the number of domestic servants increased, reaching a peak of 63 percent in the 1880 s, after which the percentage steadily declined to 43 percent in 1920s. The rise is the result of an increase in the number of middle-class housewives who, pushed by the standards of the sanitation movement, created their own demand for domestic servants. ${ }^{53}$ Employing domestic servants also offered households the possibility of displaying their wealth. As a Member of Parliament once stated: 'Domestic servants are one of the best indicators of the wealth of a person. ${ }^{54}$ Other developments that may have played a role are the withdrawal of male servants from the market - the occupation of servant was seen as unfit for and unworthy of men and a waste of human capital - and the so-called 'servants question' - a looming shortage of servants - in the 1870s. Middle-class households in particular felt they were badly served, as women's magazines in those days stated time and again. Employers and the government made every effort to relieve the apparent shortages and tried to direct young girls towards domestic service. The advent of household production innovations curbed the demand for servants rather rapidly and decreased the percentage of domestic servants after the $1880 \mathrm{~s} .{ }^{55}$ Kitchen apparel offered some relief in 1880s and 1890s. Most noteworthy is the advent of enamelled kitchenware, which was more durable and less labour-intensive in terms of cleaning and maintenance. Electric ironing entered Dutch households in the 1910s, soon to be followed by the vacuum cleaner. 
Figure 2. Percentage domestic servants among working women in the Netherlands, 1812-1922

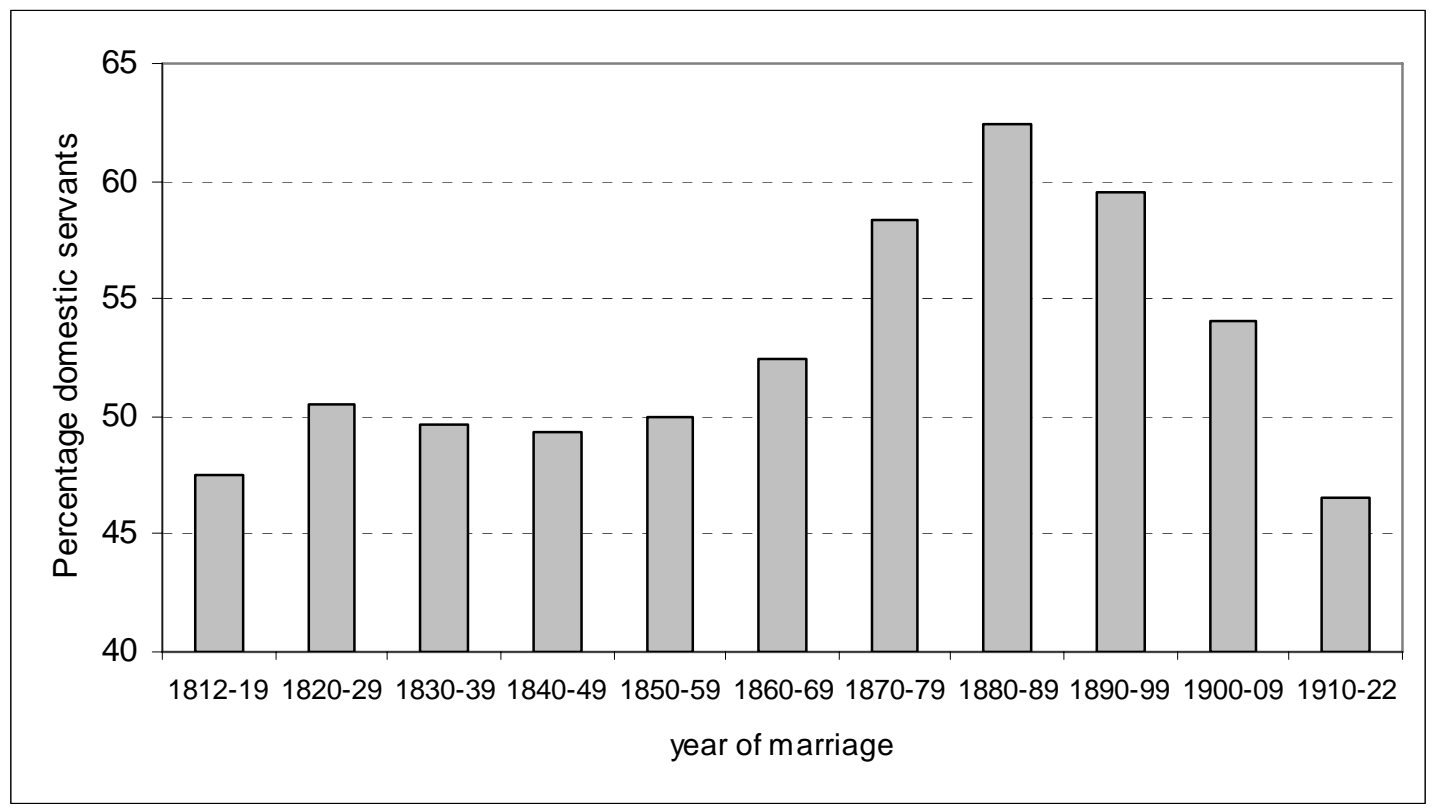

Source: GENLIAS and ISIS database

For the lower classes, the possibility of hiring servants was out of the question. Still, being a housewife became over time the dominant choice among the lower classes as well. For most couples this was hardly an affordable option, however, and for many women the pressure of having to adhere to this social norm implied working 'undercover' so people would not see that they violated the norm. The more common option in this case was to engage in a particular cottage industry, which often involved unskilled, underpaid work that was, to boot, hazardous for one's health. Cottage industries could be divided into 'in-house' work for the entire family (e.g. cigar and shoe industry, 'sorting peas'), and work that was the exclusive domain of women and girls (textiles, embroidery, knitting, laundry, etc.). ${ }^{56}$ After 1870, with the introduction of specialised machinery and factories, the cottage industry largely disappeared in some sectors, such as weaving and spinning. In the garment industry, however, women working at home were still the dominant producers. ${ }^{57}$ Working conditions in homes were, however, worse than in factories. The production of mats, for example, was a very hazardous and dusty enterprise, engaged in almost exclusively by women in their homes. This type of work was concentrated in the north-western part of 
Overijssel, where the death rate caused by tuberculosis among women by far exceeded the Dutch average: a third of the women aged 14 and older died of tuberculosis, compared with a Dutch average of 17 percent. ${ }^{58}$

\section{VI}

Place, time and social class independently affect the labour force participation of women. However, whether class differences have converged across time and place remains unclear. By introducing interaction effects in our regression analysis we were able to dig somewhat deeper into the observed relationship between social class and labour force participation across time and place. ${ }^{59}$ For the sake of brevity, we condensed the number of marriage cohorts to four, in line with the observed effects of time in Table 5. We distinguished cohorts 1812-39, 1840-69, 1870-89 and 1890-1922. In Table 8 we present the results of two models with interaction effects. Model IV includes interaction effects between social class and time, and model V studies the interaction effects between social class and region.

The main conclusion that can be drawn from model IV is that the diffusion of the social norm is a story of convergence. The upper classes were the leading classes at the start of the nineteenth century and among the higher and middle classes the housewife was a common phenomenon. By the end of the 1910s, however, entering marriage without an occupation was the dominant choice among every class. Convergence was strongest during the last time interval (1890-1922), in particular among the lower classes. The fact that the odds ratios of all classes, except for farmers' wives, were well below 1.0 among the most recent cohorts must be seen in light of the fact that the base category - unskilled farm workers - showed the strongest increase (see also Table 2). It is a fact, however, that upper-class women were more and more active in the labour market and this might result from the emergence of new types of jobs, such as secretaries, typists, and more general office work, for women. Office work was considered to be decent and respectable work and perfectly fit for women. ${ }^{60}$ In addition to engaging in administrative jobs, bettereducated women also started to work in health care, social work and education. Some form of professional or even university training was necessary for these positions and increasing numbers of women, in particular those in the upper and middle classes, participated in this form of training. 
Table 8. Logistic regression of reporting of occupation at time of marriage by women

\begin{tabular}{|c|c|c|c|c|c|}
\hline & & \multicolumn{4}{|c|}{$\begin{array}{l}\text { Probability of stating 'no occupation' by bride } \\
\text { (reporting of occupation = 0) }\end{array}$} \\
\hline & & \multicolumn{2}{|c|}{ Model IV } & \multicolumn{2}{|c|}{ Model V } \\
\hline & & Odds & t-value & Odds & t-value \\
\hline \multicolumn{6}{|c|}{ Status groom (Unskilled farm workers $=1.00)$} \\
\hline Upper class & & 38.31 & 44.49 & 47.00 & 42.32 \\
\hline White-collar middle class & & 6.18 & 78.68 & 8.43 & 96.44 \\
\hline Skilled workers & & 2.74 & 58.39 & 4.77 & 87.45 \\
\hline Farmers & & 2.53 & 57.84 & 5.75 & 83.55 \\
\hline Lower-skilled workers and & $\mathrm{m}$ workers & 2.10 & 39.20 & 3.16 & 53.82 \\
\hline Unskilled workers & & 1.68 & 30.22 & 2.21 & 46.65 \\
\hline \multicolumn{6}{|c|}{ Period of marriage $(1812-39=1.00)$} \\
\hline $1840-1869$ & & 1.35 & 21.65 & 1.42 & 50.84 \\
\hline $1870-1889$ & & 1.96 & 45.64 & 2.15 & 103.73 \\
\hline $1890-1922$ & & 4.05 & 103.27 & 3.91 & 204.40 \\
\hline \multicolumn{6}{|c|}{ Interaction Class*Period of marriage } \\
\hline \multirow{3}{*}{ Upper class } & $1840-1869$ & 0.95 & 0.47 & - & - \\
\hline & $1870-1889$ & 1.05 & 0.36 & - & - \\
\hline & $1890-1922$ & 0.28 & 13.14 & - & - \\
\hline \multirow[t]{3}{*}{ White-collar middle class } & $1840-1869$ & 0.96 & 1.51 & - & - \\
\hline & $1870-1889$ & 1.00 & 0.12 & - & - \\
\hline & $1890-1922$ & 0.73 & 11.65 & - & - \\
\hline \multirow[t]{3}{*}{ Skilled workers } & $1840-1869$ & 1.03 & 1.33 & - & - \\
\hline & 1870-1889 & 1.01 & 0.43 & - & - \\
\hline & $1890-1922$ & 0.89 & 5.58 & - & - \\
\hline \multirow[t]{3}{*}{ Farmers } & $1840-1869$ & 1.23 & 10.23 & - & - \\
\hline & $1870-1889$ & 1.52 & 18.88 & - & - \\
\hline & $1890-1922$ & 1.37 & 15.37 & - & - \\
\hline \multirow[t]{3}{*}{ Lower-skilled } & 1840-1869 & 0.95 & 2.05 & - & - \\
\hline & $1870-1889$ & 1.02 & 0.92 & - & - \\
\hline & $1890-1922$ & 0.85 & 7.49 & - & - \\
\hline \multirow[t]{3}{*}{ Unskilled workers } & 1840-1869 & 0.98 & 0.80 & - & - \\
\hline & 1870-1889 & 0.92 & 3.63 & - & - \\
\hline & $1890-1922$ & 0.71 & 16.59 & - & - \\
\hline \multicolumn{6}{|l|}{ Region $($ Zeeland $=1.00)$} \\
\hline \multicolumn{2}{|l|}{ Limburg } & 1.36 & 38.37 & 3.38 & 64.79 \\
\hline \multicolumn{2}{|l|}{ Overijssel } & 1.67 & 67.16 & 3.36 & 78.40 \\
\hline \multicolumn{2}{|c|}{ Holland (North and South Holland) } & 3.56 & 86.81 & 5.99 & 38.02 \\
\hline \multicolumn{2}{|l|}{ Gelderland } & 2.10 & 101.93 & 3.75 & 102.83 \\
\hline \multicolumn{2}{|l|}{ Groningen } & 1.68 & 67.10 & 1.46 & 28.10 \\
\hline \multicolumn{6}{|l|}{ Interaction Class*Province } \\
\hline \multirow{5}{*}{ Upper class } & Limburg & - & - & 0.19 & 14.42 \\
\hline & Overijssel & - & - & 0.44 & 6.43 \\
\hline & Holland & - & - & 0.28 & 7.00 \\
\hline & Gelderland & - & - & 0.42 & 7.39 \\
\hline & Groningen & - & - & 0.87 & 1.13 \\
\hline White-collar middle class & Limburg & - & - & 0.31 & 34.29 \\
\hline & Overijssel & - & - & 0.46 & 25.12 \\
\hline & Holland & - & - & 0.38 & 15.12 \\
\hline & Gelderland & - & - & 0.42 & 29.87 \\
\hline & Groningen & - & - & 1.18 & 5.28 \\
\hline Skilled workers & Limburg & - & - & 0.27 & 48.35 \\
\hline & Overijssel & - & - & 0.38 & 39.64 \\
\hline & Holland & - & - & 0.59 & 9.17 \\
\hline
\end{tabular}




\begin{tabular}{|c|c|c|c|c|c|}
\hline & Gelderland & - & - & 0.36 & 45.80 \\
\hline & Groningen & - & - & 0.94 & 2.44 \\
\hline \multirow{5}{*}{ Farmers } & Limburg & - & - & 0.31 & 41.56 \\
\hline & Overijssel & - & - & 0.33 & 42.71 \\
\hline & Holland & - & - & 0.39 & 12.90 \\
\hline & Gelderland & - & - & 0.36 & 42.07 \\
\hline & Groningen & - & - & 1.79 & 19.76 \\
\hline \multirow[t]{5}{*}{ Lower-skilled } & Limburg & - & - & 0.28 & 43.10 \\
\hline & Overijssel & - & - & 0.38 & 35.50 \\
\hline & Holland & - & - & 0.55 & 10.08 \\
\hline & Gelderland & - & - & 0.47 & 29.40 \\
\hline & Groningen & - & - & 1.39 & 11.19 \\
\hline \multirow[t]{5}{*}{ Unskilled workers } & Limburg & - & - & 0.36 & 38.88 \\
\hline & Overijssel & - & - & 0.40 & 39.97 \\
\hline & Holland & - & - & 0.50 & 12.95 \\
\hline & Gelderland & - & - & 0.48 & 33.37 \\
\hline & Groningen & - & - & 1.18 & 7.41 \\
\hline \multicolumn{6}{|c|}{ Rural place of residence (rural $=1.00$ ) } \\
\hline Urban & & 1.12 & 21.57 & 1.12 & 21.52 \\
\hline \multicolumn{6}{|c|}{ Age at marriage $(14-19=1.00)$} \\
\hline $20-24$ & & 0.75 & 27.99 & 0.74 & 29.46 \\
\hline $25-29$ & & 0.64 & 42.37 & 0.62 & 44.39 \\
\hline $30-34$ & & 0.59 & 46.04 & 0.57 & 47.78 \\
\hline $35-39$ & & 0.54 & 46.32 & 0.52 & 47.73 \\
\hline $40-44$ & & 0.52 & 40.40 & 0.51 & 41.54 \\
\hline $45+$ & & 0.60 & 31.38 & 0.58 & 32.65 \\
\hline \multicolumn{6}{|c|}{ First time marriage $($ remarriage $=1.00)$} \\
\hline First marriage & & 1.15 & 18.14 & 1.18 & 21.28 \\
\hline \multicolumn{2}{|l|}{$\begin{array}{l}\mathrm{N}= \\
\text { Pseudo } \mathrm{R}^{2}\end{array}$} & \multicolumn{2}{|c|}{$1,0165,573$} & & \\
\hline
\end{tabular}

Model IV also reveals an element that merits special attention as it sheds light on the diffusion of norms in the absence of wealth, viz. the emergence of the housewife among farmer couples. The odds ratios were larger than 1.0 throughout the sample period, suggesting that the adherence to the norm followed a strong, upward trend compared with the base category - the wife of an unskilled farm worker - who also showed an upward trend in this respect. In the 1910s (see Table 2) 86 percent of farmers' wives entered marriage with no occupation, although in actual practice most wives worked on the farm. However, the practice of entering marriage without an occupation must be seen as a social role rather than a question of economic rationality or a sign of wealth as agricultural labour productivity in the Netherlands showed almost no upward movement throughout the nineteenth century (see Figure 3). In other sectors of the Dutch economy - industry and services - productivity clearly started to rise around 1870. 
Figure 3: Real value added per man-hour in sectors of industry in the Netherlands, 1807-1913 (in guilders, prices 1913)

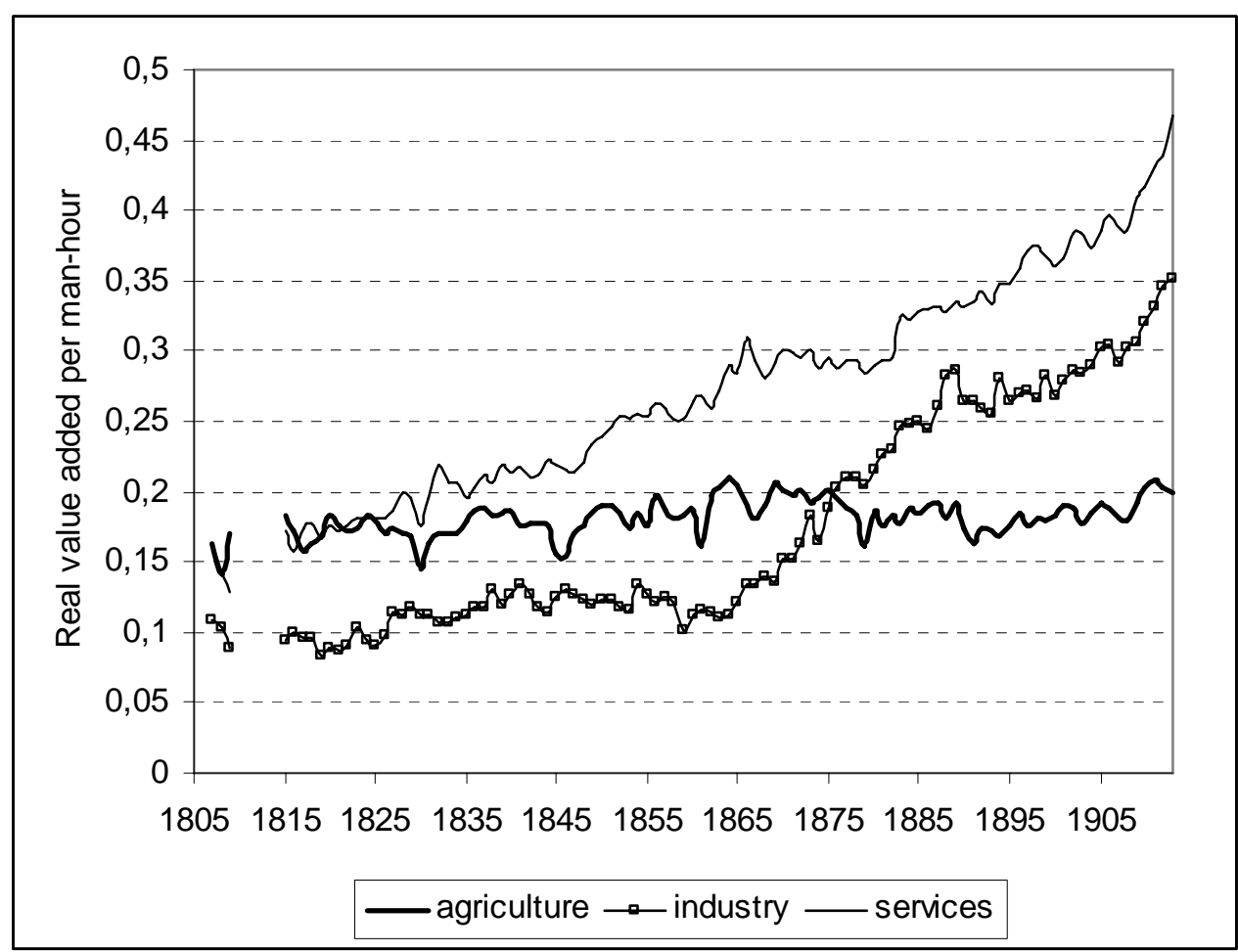

Source: National Accounts of the Netherlands, 1801-1913, http://nationalaccounts.niwi.knaw.nl

Model V of Table 8 includes interaction effects between social class and region to test for the presence of regional differences across classes. In other words, did upper class women in the province of Holland make different choices in marriage compared with upper class women in, say, Groningen? All odds ratios for the interaction effects were below 1.0, except those for the province of Groningen. The most significant conclusion one can draw from this particular model is that regional differences existed at every class level, although the choices made by women in Groningen and Zeeland were not very different among the upper and middle classes. A striking exception to this rule is the finding that farmers' wives in Limburg, Overijssel, Holland and Gelderland displayed more or less the same choices in labour market behaviour.

\section{VII}

The economic history of the household is very much like an exercise in reverse engineering. Understanding the principles of the division of labour may seem simple 
at the outset, in actual practice a deeper understanding may involve 'dismantling' the household and analysing its workings in detail and from different perspectives in order to construct a new principle that improves our understanding of the past. The household and the products and services it produces may prove to be the engine of growth. This has so far not received the attention it deserves but may well be the next phase in family history. A pluralist approach to the workings of the family is found in the economic historical work of Creighton and Horrell \& Humphries. Whereas these different approaches may have produced a more rounded understanding ${ }^{61}$, they have at the same time hampered efforts to make connections to the larger stories in economic history, as put forward by De Vries, North and Goldin. The work of North ${ }^{62}$ is particularly relevant here as institutions such as social norms play a dominant role in his long-run theory of economic change. Institutions in society cover the set of formal and informal rules (conventions, norms of behaviour and self-imposed codes of conduct) and their enforcement characteristics. Institutions are, in other words, the incentive structure, determining how 'games' in actual life are played and how the wealth of nations rises and falls. The economic significance of the household has also gained importance thanks to the ideas of De Vries who, by applying Becker's ${ }^{63}$ analytic framework, underlines the importance of the so-called Industrious Revolution, which preceded the Industrial Revolution. He stresses the demand-side effects of a switch from household production to market production, which paved the way for the Industrial Revolution. But he also notes the counterintuitive movement of the nineteenth century, when households 'living in the throes of industrialization, in the hectic drive to industrial maturity, should at the margin shift demand away from market goods.' His explanation boils down to a change of preferences, without explaining why these preferences changed. De Vries claims that 'it was more through the household productive system than the larger formal economy that the major achievements of industrial society - lower morbidity and mortality, better nutrition and higher educational levels, greater domestic comfort - were achieved' ${ }^{64}$

This study provides long-run evidence that may help us understand the lull in economic activity between the so-called Industrious Revolution and the Industrial Revolution. The latter took off rather late in the Netherlands, which makes the Netherlands an interesting case study. Our main finding is that the emergence of the housewife in the Netherlands over the period 1812-1922 was strongly influenced by the social norm that women should withdraw from the labour market on the eve of 
marriage. The emergence of the housewife developed in a clear class-specific way: in the higher social strata it was more or less the only option from the beginning of the nineteenth century, it became the dominant choice among the white-collar middle class in the first decades of the nineteenth century and later also became the dominant choice for lower-class women; it emerged as the most important alternative for women marrying a farmer after 1850 and became the most popular preference among women marrying lower or unskilled workers from the last decade of the nineteenth century. Women in urban municipalities were 10 to 20 years earlier when it came to setting the norm, and social class differences in urban areas were also larger than in rural areas. Interestingly, from this we can deduce that it is not the burden of childbearing, child rearing or the wealth of the husband that triggered this convention but the force of a social norm. This is most clearly reflected in the emergence of the housewife among the lower social classes, especially among women working in agriculture at the close of the nineteenth century. The force of the social norm explains why the work pressures of lower-class women did not change with the emergence of the housewife: to keep up appearances, they substituted registered work for unregistered work (e.g. in cottage industries, working in the family firm or on the farm).

A shortcoming of our exercise in 'reverse engineering' is that one can never be sure of the real rationale underlying the norm to enter marriage as a housewife. Distinguishing between norms and beliefs is extremely difficult, yet it seems likely that norm-driven behaviour was the rule given the low level of education of the population at the time. One should not, at least, assume too much rationality in the patterns of choice found. Mokyr suggests that the increase in housework carried out by women may have been the result of increases in knowledge about the causes and transmission mechanisms of infectious diseases. ${ }^{65}$ Based on the insights generated by the Dutch hygienic movement, one is tempted to say that individual withdrawal from the labour market was not initially inspired by health considerations or knowledge of health hazards. The emergence of the housewife started much earlier than the spread of useful health knowledge. This sheds doubt on the assumption that the decision to become a housewife was a rational, well-informed and independent choice. This situation changed, of course, when the hygienic and sanitation movement caught on in the Netherlands. And our statistics suggest that this 'knowledge force' may have sped up the diffusion of the norm of the housewife at the end of the nineteenth century. 
Dutch hygienists were relatively late in applying their knowledge to public health questions. In France and England the hygienic movements were actively involved in questions of public health from 1830 onwards; in the Netherlands the first hygienists appeared twenty years later. ${ }^{66}$ Dutch hygienists not only lagged in knowledge and experience, they also differed distinctly from the English and French in terms of their public policy stance. The foreign institutions were considered far too interventionist to be applicable to the Dutch political environment, an environment which was very conservative until 1880 when a socialist movement appeared on the scene. Public health knowledge was also disseminated with a substantial lag in labour legislation. The Dutch Labour Act (1889) and Child Act (1874), which placed restrictions on child labour and female labour participation, were relatively late in coming and their enforcement left much to be desired. In Britain, the first Labour Act dates from 1851. The view that working conditions might matter came relatively late in the nineteenth century. There was, of course, knowledge that death rates have a clear social-class gradient, but the connection with working conditions could not be firmly established and most inspectors of factories were too dogmatic to conclude that some types of work or working conditions might be hazardous.

In short, judging from our data source of marriage certificates, the nineteenth century was an era in which Dutch women withdrew from the official labour market on a large scale and social norms and social beliefs played a major role in bringing about this 'preference switch'. The flip side of the story is that the emergence of the housewife among the lower classes did not come cheaply: it left work pressures unaltered and worsened working conditions.

\section{References}

Anderson, M. Approaches to the history of the Western family 1500-1914 (London, 1980).

, 'What can the mid-Victorian censuses tell us about patterns of married women's employment?' Local Population Studies, no. 62 (1999), pp. 9-30.

Barrett, M. Women's oppression today: problems in Marxist feminist analysis (London, 1980).

Becker, G.S. 'A theory of the allocation of time' Economic Journal 75 (1965), pp. 493-517. 
Creighton, $\mathrm{C}$. 'The rise of the male breadwinner family: a reappraisal', Comparative Studies in Society and History 38 (1996), pp. 310-337.

_ , 'The rise and decline of the 'male breadwinner family' in Britain', Cambridge Journal of Economics 23 (1999), pp. 519-541.

De Haan, F., Sekse op kantoor. Over vrouwelijkheid, mannelijkheid en macht, Nederland 1860-1940 (Hilversum, 1992).

De Mare, H. 'Domesticity in dispute. A reconsideration of sources', in I. Cieraad ed., At home: An anthropology of domestic space, (New York, 1999), pp. 13-30.

De Maris, A. 'A framework for the interpretation of first-order interaction in logitmodeling', Psychological Bulletin 110 (1991), pp. 557-570.

De Regt, A. Arbeidersgezinnen en beschavingsarbeid. Ontwikkelingen in Nederland 1870-1940 - Een historisch-sociologische studie, (Meppel, 1984).

De Vries, B. M. A., Van agrarische samenleving naar verzorgingsstaat. Demografie, economie, maatschappij en cultuur in West-Europa, 1450-2000 (Groningen, 2000).

De Vries, J., 'The Industrial Revolution and the Industrious Revolution' Journal of Economic History 54, no. 2 (1994) pp. 249-270.

De Vries, J. and Van der Woude, A., The first modern economy: Success, failure, and perseverance of the Dutch economy, 1500-1815. (New York, 1997).

Duncan, S. and Smith, D. 'Geographies of Family Formations: Spatial Differences and Gender Cultures in Britain' Transactions of Institute of British Geographers 27 (2002), pp. 471-493.

Elenbaas, J. N., Handboek voor den burgerlijken stand. (Alphen aan den Rijn, 1919).

Everard, M. 'Veranderingen en continuïteit in de arbeid van vrouwen', Tijdschrift voor Economische en Sociale Geschiedenis 2, no. 3 (2005), pp. 81-102.

Folbre, N. 'The unproductive housewife: Her evolution in nineteenth-century economic thought', Signs 16, no. 3 (1991), pp. 463-484.

Goldin, C. 'The quiet revolution that transformed women's employment, education, and family' American Economic Review, Papers and Proceedings (2006) 96, pp. $1-21$.

Hakim, C. 'Census Reports as Documentary Evidence: The Census Commentaries, 1801-1951', Sociological Review 28 (1980), pp. 551-580.

Hareven, T. 'The home and the family in historical perspective', Social Research 58, no. 1 (1991), pp. 253-285. 
Hartmann, H.I. 'The unhappy marriage of Marxism and feminism: towards a more progressive union' Capitalism and Class 8 (1979), pp. 1-33.

Higgs, E. 'Women, occupations and work in the nineteenth century censuses', History Workshop 23 (1987), pp. 59-80.

Horrell, S. and Humphries, J. 'Women's labor force participation and the transition to the male breadwinner family, 1790-1865', Economic History Review 48 (1995), pp. 89-117.

- 'The origins and expansion of the male breadwinner family - The case of nineteenth-century Britain', International Review of Social History 42 Supplement 5 (1997), pp. 25-64.

Houwaart, E.S. De hygiënisten - Artsen, staat en volksgezondheid 1840-1890, (Groningen, 1991).

Janssens, A. 'The rise and decline of the male breadwinner family? An overview of the debate', International Review of Social History 42, no. Supplement 5 (1997), pp. 1-23

Kuran, T., Private truths, public lies - The social consequences of preference falsification (Harvard, 1995).

Leidraad Bevolkingsstatistiek, behoort bij beschikking dd. 22 juni 1936, nr 16301, afdeling B.B. van den minister van Binnenlandse Zaken', ('s-Gravenhage, 1936).

Leydesdorff, S., Verborgen arbeid, vergeten arbeid. Een verkenning in de geschiedenis van de vrouwenarbeid rond negentienhonderd (Assen, 1977).

Maddison, A. The world economy - Historical statistics, (Paris, 2004).

Marland, H., 'The medicalization of motherhood: doctors and infant welfare in the Netherlands, 1901-1930, in: V. Fildes, L. Marks and H. Marland eds. Women and children first - International maternal and infant welfare 1870-1945 (London, 1992), pp. 74-96.

Matthijs, K. 'Demographic and sociological indicators of privatisation of marriage in the nineteenth century in Flanders', European Journal of Population 19 (2003), pp. 375-412.

McBride, T.M. The domestic revolution - The modernisation of household services in England and France 1820-1920 (London, 1976).

Mokyr, J. The Industrial Revolution and the Netherlands: Why Did It Not Happen?, De Economist 148 (2000a), pp. 503-520. 
—_Why “More work for mothers?” Knowledge and household behavior, 18701945, Journal of Economic History 60 (2000b), pp. 1-41.

Motte, C. and Pelissier, J.-P. 'La binette, l'aiguille et le plumeau. Les mondes du travail féminin', in J. Dupâquier and D. Kessler eds., La sociéte française au XIXe siècle. Tradition, Transition, Transformation (Paris, 1995), pp. 237-342.

North, D.C. 'Some fundamental puzzles in economic history/development' in: W.B. Arthur, S.N. Durlauf and D.A. Lane eds., The economy as an evolving complex system II (Reading, 1997) pp. 223-237.

Plantenga, J., Een afwijkend patroon. Honderd jaar vrouwenarbeid in Nederland en (West-) Duitsland (Amsterdam, 1993).

Poelstra, J., Luiden van een andere beweging - Huishoudelijke arbeid in Nederland 1840-1920 (Amsterdam, 1996).

Pott-Buter, H.A., Facts and fairy tales about female labor, family and fertility: A seven-country comparison, 1850-1990 (Amsterdam, 1993).

Schilstra, W.N. Vrouwenarbeid in landbouw en industrie in Nederland in de tweede helft der negentiende eeuw (Amsterdam, 1940).

Schmidt, A. 'Vrouwenarbeid in de vroegmoderne tijd in Nederland', Tijdschrift voor Economische en Sociale Geschiedenis 2, no. 3 (2005), pp. 2-21.

Schuurman, A. J. 'Is huiselijkheid typisch Nederlands? Over huiselijkheid en modernisering', Bijdragen en mededelingen betreffende de geschiedenis der Nederlanden 107, no. 4 (1992), pp. 745-759.

Smith, G.D., and Lynch, J. 'Commentary: Social capital, social epidemiology and disease aetiology' International Journal of Epidemiology 33 (2004), pp. 691700.

Sunstein, C.R. 'Social norms and social roles' Columbia Law Review 96 (1996), pp. 903-968.

Vaillant, C. E., Handboek voor den ambtenaar van den burgerlijken stand ('sGravenhage, 1893).

Van Leeuwen, M. H. D. and Maas, I. 'HISCLASS A historical social class scheme for occupational titles in the past'. Paper presented at the XVIth International Conference of the Association for History and Computing, Amsterdam, 14-17 September 2005.

Van Leeuwen, M. H. D., Maas, I. and Miles, A., HISCO: Historical international standard classification of occupations (Leuven, 2002). 
Van Poppel, F. and Joung, I., 'Long-term trends in marital status mortality differences in the Netherlands 1850-1970' Journal of Biosocial Science 33 (2001), pp. 279-303.

Van Zanden, J. L. and Van Riel, A., The strictures of inheritance: The Dutch economy in the nineteenth century. (Princeton, 2004).

Veblen, T., The theory of the leisure class - An economic study of institutions. (New York, 1899).

Voorduin, J. C., Geschiedenis en beginselen der Nederlandse wetboeken, volgens de beraadslagingen deswege gehouden bij de Tweede Kamer der StatenGeneraal uit oorspronkelijke grootendeels onuitgegeven staatsstukken en aan den Koning opgedragen (Utrecht, 1837).

Walhout, E. and Van Poppel, F.W.A. ' De vermelding des beroeps: eene ijdele formaliteit?'. Twee eeuwen vrouwelijke beroepsarbeid in Nederlandse huwelijksakten', Tijdschrift voor sociale geschiedenis 29, no. 3 (2003), pp. 301-332.

Walker, A. 'Pleasurable homes'? Victorian model miners' wives and the family wage in a South Yorkshire Colliery district', Women's History Review 6 (1997), pp. 317-336.

\section{Notes}

${ }^{1}$ A translation of the lessons taught to school children: 'Vrouw!... Gij zijt geschapen om uw Kroost te zogen. Welk eene verantwoording bij den Schepper, zo gij, buiten den dringensten nood, hetzelve aan eenen vreemden boezem overgeeft. [... Ook lijdt het Welzijn der Maatschappij onbedenklijk veel nadeel door zulk eene onnatuurlijke gewoonte. Menig kind van den gemeenen man wordt immers daardoor van zyne natuurlijke Voedster beroofd; menig huwelijk, menig huisgezin min of meer bedorven, zowel onder den minderen als voornamen stand.'

${ }^{2}$ Cf. Creighton, 'The rise and decline of the male breadwinner family'; and Goldin 'The quiet revolution'. 
${ }^{3} \mathrm{Cf}$. Anderson, Approaches to the history of the Western family.

${ }^{4}$ See De Vries 'The Industrial Revolution', p. 263, who refers to Beckerian Z commodities' when he speaks about household products.

5 Sunstein 'Social norms', p. 913.

${ }^{6}$ Breastfeeding was not very common among the lower classes in the Netherlands of the nineteenth century.

${ }^{7}$ Kuran, Private truths, public lies, pp. 24-38.

${ }^{8}$ Veblen, The theory of the leisure class.

${ }^{9}$ Schilstra 'Vrouwenarbeid', pp. 130-131.

${ }^{10}$ Creighton, 'The rise of the male breadwinner family'.

${ }^{11}$ Hareven, 'The home and the family', p. 261.

${ }^{12}$ Creighton, 'The rise of the male breadwinner family'.

13 Barrett, Women's oppression today

14 Hartmann, 'The unhappy marriage'.

15 Smith and Lynch, 'Commentary', p. 697.

${ }^{16}$ Motte and Pelissier, 'La binette'.

${ }^{17}$ Walker, 'Pleasurable homes', p. 323.

${ }^{18}$ Matthijs, 'Demographic'.

${ }^{19}$ Walhout and Van Poppel, 'De vermelding des beroeps'.

${ }^{20}$ Janssens, 'The rise and decline', p. 6-7, 22.

${ }^{21}$ Horrell and Humphries, 'The origins and expansion', pp. 25-26.

${ }^{22}$ Mokyr, 'The industrial revolution'.

${ }^{23}$ De Vries, 'The industrial revolution'.

${ }^{24}$ Van Zanden and Van Riel, The strictures, pp. 53-64.

25 De Regt, Arbeidersgezinnen. 
${ }^{26}$ See Van Poppel and Joung, 'Long-term trends'.

27 Marland, 'The medicalization of motherhood'.

${ }^{28}$ De Vries and Van der Woude, The first modern economy, p.599.

${ }^{29}$ Schmidt, 'Vrouwenarbeid', p. 6.

${ }^{30}$ Pott-Buter, Facts and fairy tales, pp. 31-321.

${ }^{31}$ Plantenga, Een afwijkend patroon, p. 189.

${ }^{32}$ Van Zanden and Van Riel, The strictures, pp. 323.

${ }^{33}$ De Vries and Van der Woude, The first modern economy, pp. 604- 605.

${ }^{34}$ But the authors' ideas about the early appearance of the ideology of domesticity have been critised as well. See De Mare, 'Domesticity', Everard, 'Veranderingen en continuïteit', pp. 83-84: Schuurman, 'Is huiselijkheid'.

${ }^{35}$ De Vries and Van der Woude, The first modern economy pp. 603, Schmidt, 'Vrouwenarbeid', p. 20.

${ }^{36}$ Hakim, 'Census reports', p. 562.

${ }^{37}$ In his article 'What can the mid-Victorian censuses tell us', Anderson evaluates the criticism on using census data to measure female employment and concludes that one should discard census data 'as almost useless for serious analytical purposes', as seems to have become the norm in historical research (e.g. Horrell and Humphries, ibid., and Folbre, 'The unproductive housewife').

${ }^{38}$ Janssens, 'The rise and decline of the male breadwinner family?', pp. 22-23.

${ }^{39}$ Voorduin, Geschiedenis, pp. 87-89.

${ }^{40}$ Ibid., pp. 57.

${ }^{41}$ Vaillant, Handboek, pp. 329-330; Elenbaas, Handboek.

${ }^{42}$ Leidraad, p. 14.

${ }^{43}$ Motte and Pelissier, 'La binette', pp. 242-244. 
${ }^{44}$ The acronym GENLIAS is a contraction of the words 'genealogy' (research into family trees) and 'lias' (a bundle of papers tied together, a filing method frequently used in the past). For more information see: http://www.genlias.nl/en/page0.jsp 45 In most cases, the place where the marriage was contracted was the woman's place of residence. Marriages had to be contracted in the place of residence of one of the spouses.

${ }^{46}$ Van Leeuwen, Maas, Miles, HISCO.

${ }^{47}$ Van Leeuwen and Maas, 'HISCLASS'.

${ }^{48}$ We have classified retired men and women under their old occupation and people who gave a double occupation under the first one. People in military service were, where possible, classified under the heading of their occupation.

${ }^{49}$ See Higgs, 'Women', p. 68 for a comparable problem.

50 Pott-Buter, Facts and fairy tales, p. 21.The trend depicted in Figure 1 more or less follows the pattern described in the literature based on data from the censuses held between 1850 and 1920. It is important to note, however, that in the censuses until 1900 data for all married and unmarried women were available whereas Figure 1 represents mainly young recently married women.

51 Duncan and Smith 'Geographies of family formation'

${ }^{52}$ De Vries, Van agrarische samenleving, p. 66.

53 Poelstra, Luiden van een andere beweging, p. 53.

${ }^{54}$ See Poelstra, ibid, p. 41.

${ }^{55}$ This development is in line with the rise and fall in the number of servants in France, see McBride, The domestic revolution.

56 See Leydesdorff, Verborgen arbeid, in particular Chapter 7.

57 Schilstra Vrouwenarbeid, pp. 11-13. 
58 Ibid. pp. 130-131.

${ }^{59}$ De Maris, 'A framework'.

${ }^{60}$ De Haan, Sekse op kantoor, pp. 18-19, 261.

${ }^{61}$ Anderson, Approaches to the history of the Western family.

${ }^{62}$ North, 'Some fundamental puzzles'.

${ }^{63}$ Becker, 'Theory of allocation of time'.

${ }^{64}$ De Vries, 'The Industrial Revolution', p. 264.

${ }^{65}$ Mokyr, 'Why 'More work for mothers?'

${ }^{66}$ Houwaart, De hygiënisten, pp. 19-20. 